\title{
Why do arms extract less oxygen than legs during exercise?
}

J. A. L. Calbet, H.-C. Holmberg, H. Rosdahl, G. van Hall, M. Jensen-Urstad and

B. Saltin

Am J Physiol Regul Integr Comp Physiol 289:1448-1458, 2005. First published May 26, 2005;

doi:10.1152/ajpregu.00824.2004

You might find this additional information useful...

This article cites 73 articles, 45 of which you can access free at:

http://ajpregu.physiology.org/cgi/content/full/289/5/R1448\#BIBL

Updated information and services including high-resolution figures, can be found at: http://ajpregu.physiology.org/cgi/content/full/289/5/R1448

Additional material and information about American Journal of Physiology - Regulatory, Integrative and Comparative Physiology can be found at:

http://www.the-aps.org/publications/ajpregu

This information is current as of October 13, 2005 .

The American Journal of Physiology - Regulatory, Integrative and Comparative Physiology publishes original investigations that illuminate normal or abnormal regulation and integration of physiological mechanisms at all levels of biological organization, ranging from molecules to humans, including clinical investigations. It is published 12 times a year (monthly) by the American Physiological Society, 9650 Rockville Pike, Bethesda MD 20814-3991. Copyright ( 2005 by the American Physiological Society. ISSN: 0363-6119, ESSN: 1522-1490. Visit our website at http://www.the-aps.org/. 


\title{
Why do arms extract less oxygen than legs during exercise?
}

\author{
J. A. L. Calbet, ${ }^{1,2}$ H.-C. Holmberg, ${ }^{3}$ H. Rosdahl, ${ }^{4}$ G. van Hall, ${ }^{2}$ M. Jensen-Urstad, ${ }^{5}$ and B. Saltin ${ }^{2}$ \\ ${ }^{1}$ Department of Physical Education, University of Las Palmas de Gran Canaria, Canary Islands, Spain; \\ ${ }^{2}$ The Copenhagen Muscle Research Center, Rigshospitalet, Copenhagen, Denmark; Departments of \\ ${ }^{3}$ Physiology-Pharmacology and ${ }^{4}$ Cardiology, Karolinska Institute, Stockholm; and ${ }^{5}$ Department of \\ Sport and Health Sciences, University College of Physical Education and Sports, Stockholm, Sweden
}

Submitted 6 December 2004; accepted in final form 13 May 2005

Calbet, J. A. L., H.-C. Holmberg, H. Rosdahl, G. van Hall, M. Jensen-Urstad, and B. Saltin. Why do arms extract less oxygen than legs during exercise? Am J Physiol Regul Integr Comp Physiol 289: R1448-R1458, 2005. First published May 26, 2005; doi:10.1152/ajpregu.00824.2004.-To determine whether conditions for $\mathrm{O}_{2}$ utilization and $\mathrm{O}_{2}$ off-loading from the hemoglobin are different in exercising arms and legs, six cross-country skiers participated in this study. Femoral and subclavian vein blood flow and gases were determined during skiing on a treadmill at $\sim 76 \%$ maximal $\mathrm{O}_{2}$ uptake $\left(\dot{\mathrm{V}}_{2}\right.$ max $)$ and at $\dot{\mathrm{V}}_{2}$ max with different techniques: diagonal stride (combined arm and leg exercise), double poling (predominantly arm exercise), and leg skiing (predominantly leg exercise). The percentage of $\mathrm{O}_{2}$ extraction was always higher for the legs than for the arms. At maximal exercise (diagonal stride), the corresponding mean values were 93 and $85 \%(n=3 ; P<0.05)$. During exercise, mean arm $\mathrm{O}_{2}$ extraction correlated with the $\mathrm{PO}_{2}$ value that causes hemoglobin to be $50 \%$ saturated $\left(\mathrm{P}_{50}: r=0.93, P<0.05\right)$, but for a given value of $\mathrm{P}_{50}, \mathrm{O}_{2}$ extraction was always higher in the legs than in the arms. Mean capillary muscle $\mathrm{O}_{2}$ conductance of the arm during double poling was $14.5(\mathrm{SD} 2.6) \mathrm{ml} \cdot \mathrm{min}^{-1} \cdot \mathrm{mmHg}^{-1}$, and mean capillary $\mathrm{PO}_{2}$ was 47.7 (SD 2.6) $\mathrm{mmHg}$. Corresponding values for the legs during maximal exercise were 48.3 (SD 13.0) $\mathrm{ml} \cdot \mathrm{min}^{-1}$. $\mathrm{mmHg}^{-1}$ and 33.8 (SD 2.6) $\mathrm{mmHg}$, respectively. Because conditions for $\mathrm{O}_{2}$ off-loading from the hemoglobin are similar in leg and arm muscles, the observed differences in maximal arm and leg $\mathrm{O}_{2}$ extraction should be attributed to other factors, such as a higher heterogeneity in blood flow distribution, shorter mean transit time, smaller diffusing area, and larger diffusing distance, in arms than in legs.

diffusing capacity; fatigue; oxygen extraction; performance; training

MUSCULAR OXYGEN UPTAKE depends on extrinsic factors such as $\mathrm{O}_{2}$ delivery and the intrinsic factors that regulate both the transfer of $\mathrm{O}_{2}$ from the erythrocytes to the mitochondria and the subsequent utilization of $\mathrm{O}_{2}$ in the mitochondria. However, the diffusive transfer of $\mathrm{O}_{2}$ is not only determined by intrinsic factors, because it also depends on mean capillary $\mathrm{O}_{2}$ tension. It is currently assumed that during exercise with a small muscle mass, intrinsic factors are the main determinants of peak local muscular $\dot{\mathrm{V}}_{2}$, because the $\mathrm{O}_{2}$ delivery is extraordinary high (3, $44,61)$. During exercise with a large muscle mass, the $\mathrm{V}_{2}$ peak of the lower extremities appears to be $\mathrm{O}_{2}$ delivery dependent $(6,7,16,33,35,57) . \mathrm{O}_{2}$ extraction across the lower extremities may reach maximal values between 90 and $92 \%$ of the arterial $\mathrm{O}_{2}$ content $\left(\mathrm{Ca}_{\mathrm{O}_{2}}\right)$, and the $\mathrm{PO}_{2}$ in the femoral vein may be close to $10 \mathrm{mmHg}$ in active subjects $(6,7,16)$, leaving little room for further extraction. However, in sedentary subjects, the maximal $\mathrm{O}_{2}$ extraction across the legs lies close to $70 \%$ of the $\mathrm{Ca}_{\mathrm{O}_{2}}$

Address for reprint requests and other correspondence: J. A. L. Calbet, Departamento de Educación Física, Campus Universitario de Tafira, 35017 Las Palmas de Gran Canaria, Canary Islands, Spain (e-mail: lopezcalbet@terra.es).
(59), implying that their peak muscular $\dot{\mathrm{V}}_{2}$ also may be limited by intrinsic factors (20). In physically active but nonarm-trained subjects, a low $\mathrm{O}_{2}$ extracting capacity has been reported for the arms $(1,11,51,70)$. Moreover, arm training resulted in only a marginal improvement in the $\mathrm{O}_{2}$ extraction of the arms (51). Therefore, the intrinsic factors may play an important role in limiting the maximal $\dot{\mathrm{V}}_{2}$ attainable during maximal arm exercise. One of these roles could be differences in muscle capillarization that may affect both mean transit time (MTT) and diffusion conditions in the muscle. Moreover, primarily on the basis of experiments using the isolated hindlimb preparation in rats, it has been shown that mitochondrial oxidative capacity could determine the rate of $\mathrm{O}_{2}$ utilization and thereby $\mathrm{O}_{2}$ extraction $(22,37,58)$. However, the limiting factor may be different in humans as suggested by the fact that prolonged bed rest decreases mitochondrial oxidative capacity and $\dot{\mathrm{V}}_{2}$ max without reducing $\mathrm{O}_{2}$ extraction in humans (13, 62). Moreover, whole body $\mathrm{V}_{2}$ increases by $6 \%$ with hyperoxia (fraction of inspired $\mathrm{O}_{2}=0.5$ ) during arm-cranking exercise (27). This observation is also compatible with a $\mathrm{O}_{2}$ delivery limitation of arm peak $\dot{\mathrm{V}}_{2}$. However, the effect of hyperoxia also could be explained, but only in part, by the increase in the amount of free $\mathrm{O}_{2}$ in the arterial blood in subjects without exercise-induced hypoxemia. Therefore, we hypothesize that $\mathrm{O}_{2}$ extraction across the arms is low because of a less efficient $\mathrm{O}_{2}$ off-loading from the hemoglobin compared with the legs.

The aim of this study was to determine, first, whether $\mathrm{O}_{2}$ extraction of the arm muscles is lower than that of leg muscles in humans with well-trained arm and leg muscles, at given systemic and regional absolute $\dot{\mathrm{V}}_{2}$. Second, we assessed whether the conditions for the $\mathrm{O}_{2}$ off-loading from the hemoglobin are different for the arms and legs during submaximal and maximal combined arm and leg exercise in arm- and leg-trained humans. Third, we assessed whether differences in muscle oxidative capacity could account for the differences in $\mathrm{O}_{2}$ extraction between arm and leg muscles. To pursue these aims, we studied a group of well-trained cross-country skiers.

\section{METHODS}

Subjects. Six elite cross-country skiers, age 24 (SD 4) yr, height 180 (SD 6) $\mathrm{cm}$, and weight 74 (SD 6) $\mathrm{kg}$, volunteered to participate in the study. One week before the experiment, their maximal $\mathrm{O}_{2}$ uptake $\left(\dot{\mathrm{V}}_{2}\right.$ max $)$ was 5.1 (SD 0.3) $1 / \mathrm{min}$ or 72 (SD 4) $\mathrm{ml} \cdot \mathrm{kg}^{-1} \cdot \mathrm{min}^{-1}$, assessed during an incremental intensity test to exhaustion. The incremental exercise test was carried out on skiers using the diagonal

The costs of publication of this article were defrayed in part by the payment of page charges. The article must therefore be hereby marked "advertisement" in accordance with 18 U.S.C. Section 1734 solely to indicate this fact. 
stride technique while skiing uphill with roller skis on a modified treadmill (Refox, Falun, Sweden). This $\dot{V}_{\mathrm{O}_{2}}$ max value is referred to as $\dot{\mathrm{V}}_{2}$ max DS. All subjects were informed about the possible risks and discomfort involved in the study before they gave their written consent to participate. This study was carried out according to the Declaration of Helsinki and was approved by the Ethical Committee of the Karolinska Institute, Stockholm, Sweden. The reason for choosing cross-country skiers was not only that they have well-trained arm and leg muscles but also that they are able to skillfully perform exercise with the upper or lower extremities, as well as exercise combining the upper and lower extremities in the upright position.

Experiment preparation. All subjects were familiar with the use of roller skies. On the experimental day, the subjects reported to the laboratory at 8:00 AM, and catheters were placed under local anesthesia (2\% lidocaine) and advanced to the final position under fluoroscopic guidance, as previously described $(9,69)$. An 18-gauge catheter (Hydrocath; Ohmeda, Swindon, UK) was inserted percutaneously, using the Seldinger technique, into the left or right femoral artery $2-5 \mathrm{~cm}$ below the inguinal ligament and was advanced $5-10 \mathrm{~cm}$ in the proximal direction. This catheter was connected to a blood pressure transducer positioned at the height of the fourth intercostal space (T100209A; Baxter, Unterschleissheim, Germany) and was also used to sample arterial blood. A 20-gauge catheter was inserted in the left femoral vein $2 \mathrm{~cm}$ below the inguinal ligament and was advanced 5-7 cm in the distal direction for femoral venous blood sampling. In the right femoral vein, a venous catheter with side holes (Radiopack TFE; Cook, Bjaerverskov, Denmark) was inserted and advanced $\sim 5$ $\mathrm{cm}$ proximal to the inguinal ligament for the injection of iced physiological saline solution. A thin polyethylene-coated thermistor (model 94-030-2.5F T.D. Edslab probe; Baxter, Irvine, CA) was inserted through the venous catheter for blood flow measurements by using the constant infusion thermodilution technique (3). An additional 18-gauge catheter also was inserted into the left femoral vein $2-3 \mathrm{~cm}$ below the inguinal ligament and was advanced under fluoroscopic guidance until the tip was positioned in the center of the right atrium, to sample blood from the right atrium. The last catheter, a Swan-Ganz triple-lumen catheter (model 132F5 Edslab) was inserted into an antecubital vein and, under fluoroscopic guidance, was advanced into the subclavian vein until the tip was positioned at $5 \mathrm{~cm}$ before the merger with the jugular vein. One lumen was used for blood sampling and another for infusion of iced saline solution for blood flow measurements. Infusate temperatures were measured with a thermistor set in a flow-through chamber (model 93-505 Edslab) connected to the venous catheters. All sampling catheters were connected to a three-way stopcock and, along with the thermistor, were sutured to the skin to minimize the risk of movement during exercise.

A three-lead electrocardiogram (ECG) was displayed on a monitor during catheterization and the rest of the experimental procedures (Dialogue 2000, Danica, Copenhagen, Denmark). The ECG, blood pressure, and the temperatures registered by the thermistors, as well as the infusate temperatures, were recorded simultaneously with the data acquisition system (MacLab 16/s; ADInstruments, Sydney, Australia). Once the catheterization was finished, the subjects lay in the supine position for $180 \mathrm{~min}$. One hour later, muscle biopsies were obtained from the vastus lateralis and, in three subjects, also from the deltoid muscle. Muscle samples were divided into two pieces. One piece was immediately frozen in liquid nitrogen. The other piece was mounted in an embedding medium (Tissue-TEK ACT compound; Miles Diagnostics, Elkhart, IN), frozen in isopentane, cooled to its freezing point in liquid nitrogen, and stored at $-80^{\circ} \mathrm{C}$. Two hours after catheterization, resting parameters were measured and blood samples were obtained three times, 15 min apart. Femoral and subclavian venous blood flows were measured just before blood sampling and again after sampling.

Exercise protocol. Classic skiing involves different techniques. The diagonal stride technique involves both the arms and the legs and is used uphill (Fig. 1). The double poling technique mainly involves the upper body (arms) and is used on flat terrain and slightly uphill. Leg skiing is diagonal skiing without poles, which means that, in contrast to diagonal skiing, all the propulsive forces are generated only by the legs. The protocol consisted of $40 \mathrm{~min}$ of continuous diagonal stride (referred to as continuous arm + leg) at $77 \%$ of $\dot{\mathrm{V}}_{2}$ max DS, followed without breaks by 10 min of double poling (arm) at $74 \%$ of $\dot{\mathrm{V}}_{2}$ max DS, 10 min of diagonal stride ( $\mathrm{arm}+\mathrm{leg}$ ) at $77 \%$ of $\dot{\mathrm{V}}_{2}$ max $\mathrm{DS}$, and 10 min of leg skiing (leg) at $78 \%$ of $\dot{\mathrm{V}}_{2}$ max DS. These conditions elicited a whole body $\dot{\mathrm{V}}_{2}$ close to $4 \mathrm{l} / \mathrm{min}$. The speed of the treadmill was then reduced, and after 3 min of active recovery, while subjects skied with the diagonal technique at $30-40 \%$ of $\dot{\mathrm{V}}_{2} \max \mathrm{DS}$, the speed and slope of the treadmill was increased every minute until subjects reached exhaustion, which occurred within 6-8 min. Blood samples were taken after 21,24 , and 36 min of continuous arm + leg skiing and then $\sim 5-7$ min after the start of arm, arm + leg, and leg skiing, respectively.

At the end of the exercise, the position of the subclavian vein and right atrium catheters was checked with fluoroscopy. No catheter was found displaced during the experiment.

Respiratory variables. Whole body $\dot{\mathrm{V}}_{2}, \mathrm{CO}_{2}$ production, and ventilation were measured continuously using an ergo spirometry system (AMIS 2001; Innovision, Odense, Denmark), which was calibrated with high-precision gases $\left(16.00 \pm 0.04 \% \mathrm{O}_{2}\right.$ and $4.00 \pm$ $0.1 \% \mathrm{CO}_{2}$; Air Liquide, Kungsängen, Sweden). During submaximal exercise, the $\dot{\mathrm{V}}_{2}$ values obtained during the last 4 min were averaged. The $\dot{\mathrm{V}}_{2}$ max was calculated as the average of the three highest 10 -s consecutive measurements of $\mathrm{O}_{2}$ uptake.

Blood flow. Femoral and subclavian venous blood flow were measured using constant-infusion thermodilution, as described in detail elsewhere (3). Briefly, iced saline was infused (Harvard pump; Harvard Apparatus, Millis, MA) through the femoral and subclavian veins simultaneously at flow rates sufficient to decrease blood temperature at the thermistor by $0.5-1^{\circ} \mathrm{C}$. At rest, saline infusions were continued for at least $60 \mathrm{~s}$, whereas during exercise, infusions 15-20 s long were used until femoral vein temperature had stabilized at its new lower value. Blood flow was calculated on the basis of thermal balance principles, as detailed by Andersen and Saltin (3). Resting blood flow and arterial blood pressure were measured six times over $60 \mathrm{~min}$ and averaged. During submaximal exercise, blood flow measurements were performed in duplicate. The reported submaximal blood flow values represent the average of at least two measurements. At peak effort, the measurements were made within 1 min of exhaustion.

Leg and Arm $\dot{V}_{2}$. Leg and arm $\dot{\mathrm{V}}_{2}$ values were computed separately using the Fick method, i.e., leg $\dot{\mathrm{V}}_{2}=$ leg blood flow $\times$ $\left(\mathrm{Ca}_{\mathrm{O}_{2}}-\mathrm{Cfv}_{\mathrm{O}_{2}}\right)$, and arm $\dot{\mathrm{V}}_{2}=$ subclavian vein blood flow $\times$ $\left(\mathrm{Ca}_{\mathrm{O}_{2}}-\mathrm{Csv}_{\mathrm{O}_{2}}\right)$, where $\mathrm{Cfv}_{\mathrm{O}_{2}}$ represents the $\mathrm{O}_{2}$ content in the femoral vein and $\mathrm{Csv}_{\mathrm{O}_{2}}$ represents the $\mathrm{O}_{2}$ content in the subclavian vein.

Histochemical and enzymatic analysis. Serial transverse sections were stained for myofibrillar ATPase as described by Brooke and Kaiser (5). Muscle capillary density was analyzed, visualized, and quantified as described by $\mathrm{Qu}$ et al. (50). Muscle biopsies were analyzed for citrate synthase (CS) and 3-hydroxyacyl-CoA dehydrogenase (HAD) activity (69).

Blood samples and analytical procedures. Blood was sampled anaerobically in heparinized syringes and immediately analyzed for hemoglobin $(\mathrm{Hb}), \mathrm{O}_{2}$ saturation (OSM3 hemoxymeter; Radiometer, Copenhagen, Denmark), blood $\mathrm{pH}, \mathrm{CO}_{2}$, and $\mathrm{O}_{2}$ tension (ABL5; Radiometer). Blood gases were corrected for measured femoral vein blood temperature (femoral venous and arterial blood gases) and subclavian vein blood temperature (subclavian venous blood gases). Blood $\mathrm{O}_{2}$ content was computed from the saturation $\left(\mathrm{SO}_{2}\right)$ and $\mathrm{Hb}$ concentration $([\mathrm{Hb}])$, i.e., $\left(1.34 \times[\mathrm{Hb}] \times \mathrm{So}_{2}\right)+\left(0.003 \times \mathrm{Po}_{2}\right)$. Another blood sample was taken, and the blood was collected in ice-cold tubes that contained $10 \mu \mathrm{l}$ of $0.33 \mathrm{M}$ EDTA per milliliter of blood and was immediately centrifuged at $4^{\circ} \mathrm{C}$ for $10 \mathrm{~min}$ and stored at $-50^{\circ} \mathrm{C}$ until analysis. Plasma was analyzed enzymatically for 

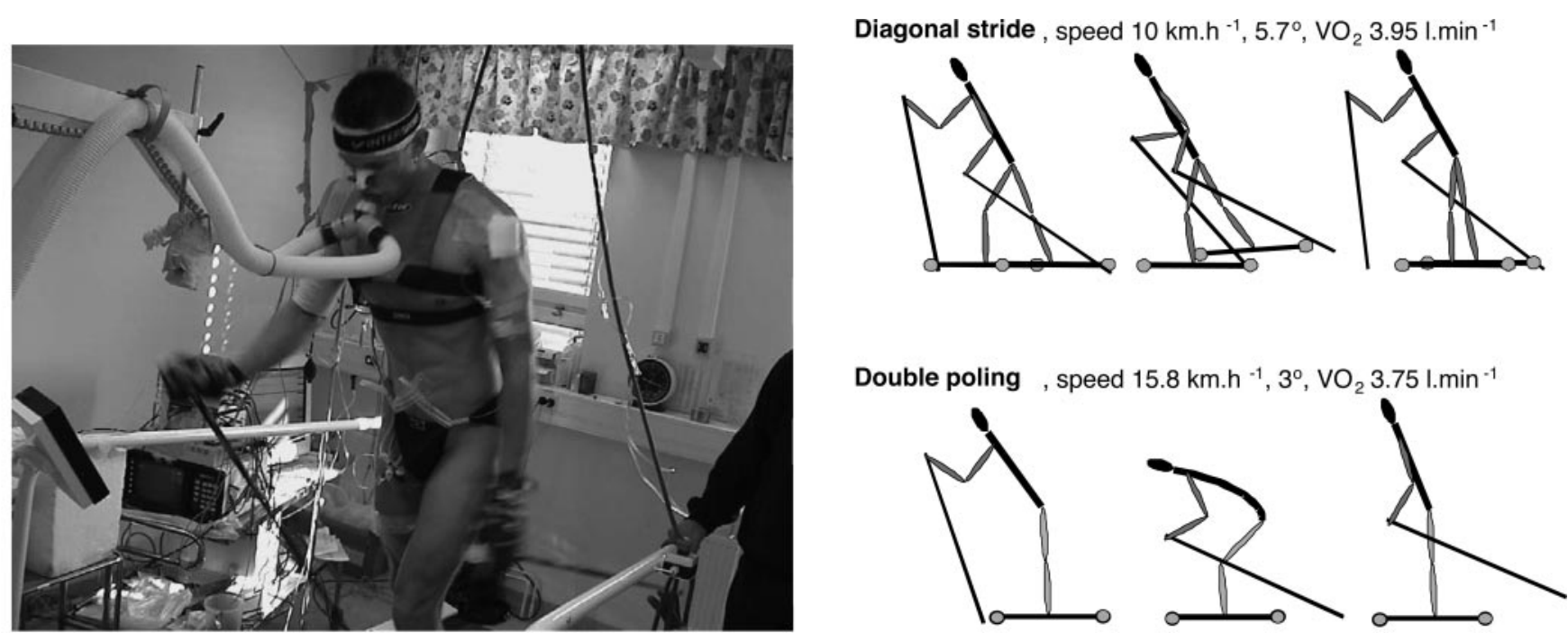

Double poling , speed $15.8 \mathrm{~km} \cdot \mathrm{h}^{-1}, 3^{\circ}, \mathrm{VO}_{2} 3.75 \mathrm{I} \cdot \mathrm{min}^{-1}$
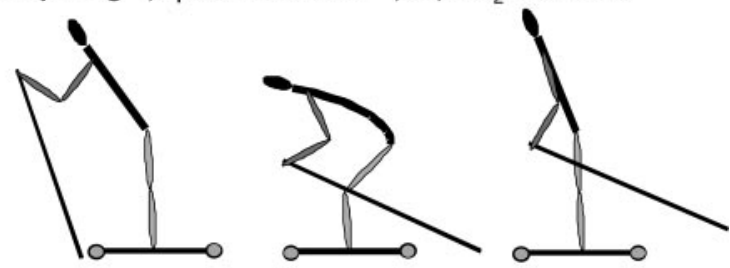

Leg skiing, speed $8.6 \mathrm{~km} \cdot \mathrm{h}^{-1}, 6.9^{\circ}, \mathrm{VO}_{2} 3.97 \mathrm{I} \cdot \mathrm{min}^{-1}$
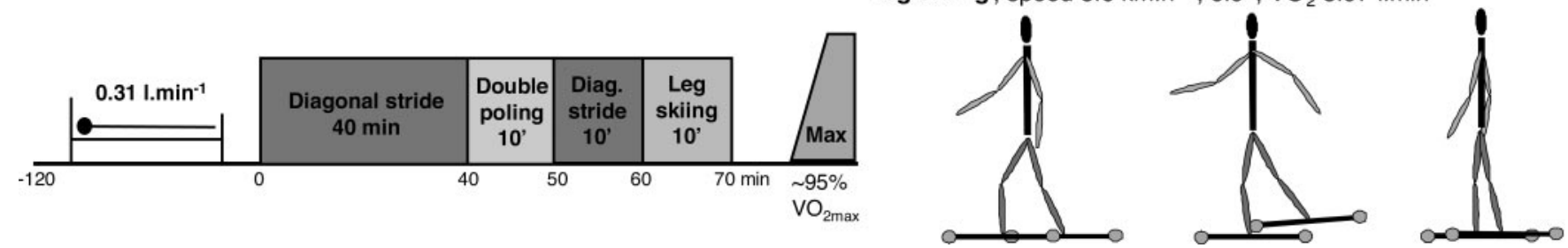

Fig. 1. Experimental protocol indicates speed and inclination of the treadmill during roller skiing. The order in which the different skiing techniques were applied is illustrated at bottom left. $\mathrm{V}_{2}$ max , maximal $\mathrm{O}_{2}$ uptake.

lactate (Roche Unikit; Hoffman-LaRoche, Basel, Germany) on an automatic analyzer (Cobas Fara; Roche Diagnostics, Basel, Switzerland). Before biochemical analysis, muscle biopsy samples were freeze-dried and dissected free of connective tissue, visible fat, and blood with the use of a stereomicroscope. The standard $\mathrm{P}_{50}$, defined as the value of $\mathrm{PO}_{2}$ that causes $\mathrm{Hb}$ to be saturated by $50 \%$ when the $\mathrm{O}_{2} \mathrm{Hb}$ equilibration curve is determined at $37^{\circ} \mathrm{C}, \mathrm{pH}=7.40, \mathrm{PCO}_{2}=40$ $\mathrm{mmHg}$, was calculated from the whole set of arterial and venous gases obtained in each experiment. The in vivo $\mathrm{P}_{50}$ was calculated using Kelman's equation (32). The in vivo $\mathrm{P}_{50}$ is the $\mathrm{PO}_{2}$ value that causes $\mathrm{Hb}$ to be saturated at $50 \%$ at the temperature, $\mathrm{PCO}_{2}$, and $\mathrm{pH}$ of the blood in the femoral and subclavian veins during exercise. Arm and leg muscle $\mathrm{O}_{2}$ conductance and mean capillary $\mathrm{PO}_{2}$ values were determined as previously described by Wagner $(71,73)$.

Capillary muscle $\mathrm{O}_{2}$ conductance and mean capillary $\mathrm{PO}_{2}$. To calculate the diffusing capacity for $\mathrm{O}_{2}\left(\mathrm{D}_{\mathrm{O}_{2}}\right)$, we used an iterative numerical integration procedure to find the value of $\mathrm{O}_{2}$ conductance (i.e., in $\mathrm{ml} \cdot \mathrm{min}^{-1} \cdot \mathrm{mmHg}^{-1}$ ) that yields the measured femoral muscle venous $\mathrm{PO}_{2}$. The calculation of $\mathrm{D}_{\mathrm{O}_{2}}$ assumes 1 ) that the intracellular $\mathrm{PO}_{2}$ is negligibly small at $\dot{\mathrm{V}}_{2}$ max $\left.(15,54), 2\right)$ that the $\mathrm{O}_{2}$ remaining in the femoral and subclavian venous blood is wholly accountable for by diffusion limitation of $\mathrm{O}_{2}$ from the microcirculation to the mitochondria, and 3) that perfusion/ $/ \mathrm{V}_{2}$ heterogeneity and perfusional or diffusional shunt are negligible. Mean capillary $\mathrm{PO}_{2}$ is the numerical average of all computed $\mathrm{PO}_{2}$ values, equally spaced in time, along the capillary from the arterial to venous end (49).

Statistical analysis. Descriptive statistics were performed on each variable to confirm the assumptions of normality and homoscedasticity. The effect of the skiing technique during submaximal exercise on the dependent variables was assessed using a one-way repeatedmeasures analysis of variance (ANOVA). Mauchly's test of sphericity was run before the ANOVA, and in case of violation of the sphericity assumption, the degrees of freedom were adjusted according to the
Huynh and Feldt test. Pairwise comparisons were carried out with Tukey's test. The relationship between muscular $\mathrm{O}_{2}$ conductance and $\mathrm{O}_{2}$ extraction was determined using linear regression. Maximal exercise values were obtained in only three subjects. Thus we decided not to perform comparisons between submaximal and maximal exercise. However, to test for differences between arm and leg variables during maximal exercise in these three subjects, we used a paired Student's $t$-test. The significance level was set at $P<0.05$. Data are expressed as means $\pm \mathrm{SD}$, unless otherwise stated.

\section{RESULTS}

$\mathrm{O}_{2}$ delivery and consumption. During submaximal exercise, whole body $\dot{\mathrm{V}}_{2}$ was similar during the different exercise conditions at $41 / \mathrm{min}$, which represented $\sim 76 \%$ of $\dot{\mathrm{VO}}_{2} \max$ measured during diagonal skiing ( $\dot{\mathrm{V}}_{2}$ max $\mathrm{DS}$; Table 1). At peak exercise, a $\dot{V}_{2}$ close to $95 \%$ of $\dot{V}_{O_{2}}$ max $\mathrm{DS}$ was reached. The contribution of the legs to whole body $\dot{\mathrm{V}}_{2}$ varied between 46\% (during double poling) and 67\% (during leg skiing). Conversely, for the arms, the corresponding values were 37 and $9 \%$, respectively (Table 1$)$. $\dot{\mathrm{V}}_{2}$ peak during double poling is a little lower ( $\sim 86 \%$ of the $\dot{\mathrm{V}}_{2}$ max DS) (Holmberg et al., unpublished observations). This means that compared with the specific double poling $\dot{\mathrm{V}}_{2}$ peak, the skiers were working at $86 \%$ of the double poling $\dot{\mathrm{V}}_{2}$ peak.

Activities of muscle oxidative enzymes. The activities of muscle oxidative enzymes have been previously reported (69) and are summarized in Table 4 together with some additional unpublished data also obtained from cross-country skiers.

$\mathrm{O}_{2}$ extraction. The effect of the exercise on the blood gases, $\mathrm{pH}$, and lactate is depicted in Table 2. The systemic and leg $\mathrm{O}_{2}$ 
Table 1. $\mathrm{O}_{2}$ delivery and $\dot{\mathrm{V}}_{2}$

\begin{tabular}{|c|c|c|c|c|c|c|}
\hline & Resting & Diagonal Skiing & Double Poling & Diagonal Skiing & Leg Skiing & $\begin{array}{l}\text { Diagonal Skiing } \\
\text { (Maximal) }\end{array}$ \\
\hline Systemic $\mathrm{O}_{2}$ delivery & 1.86 (SD 0.47) & $5.22(\mathrm{SD} 0.59)$ & $5.00(\mathrm{SD} 0.56)$ & 4.95 (SD 0.49) & 4.99 (SD 0.51) & $5.70(\mathrm{SD} 0.95)$ \\
\hline 2-Leg $\mathrm{O}_{2}$ delivery & $0.33(\mathrm{SD} 0.12)$ & $2.53(\mathrm{SD} 0.39)^{* \dagger}$ & $2.05(\mathrm{SD} 0.39)^{*}$ & $2.52(\mathrm{SD} 0.27)^{* \dagger}$ & $3.00(\mathrm{SD} 0.24)$ & $3.44(\mathrm{SD} 0.54)$ \\
\hline Pulmonary $\dot{\mathrm{V}}_{2}$ & $0.31(\mathrm{SD} 0.05)$ & $3.94(\mathrm{SD} 0.32)$ & $3.74(\mathrm{SD} 0.44)$ & $4.00(\mathrm{SD} 0.29)$ & 3.96 (SD 0.42) & 5.07 (SD 0.69) \\
\hline 2-Leg $\dot{\mathrm{VO}}_{2}$ & 0.08 (SD 0.05) & $2.19(\mathrm{SD} 0.37)^{* \dagger}$ & $1.72(\mathrm{SD} 0.42)^{*}$ & $2.27(\text { SD } 0.22)^{* \dagger}$ & $2.64(\mathrm{SD} 0.27)$ & $3.22(\mathrm{SD} 0.61)$ \\
\hline 2-Arm $\mathrm{VO}_{2}$ & 0.06 (SD 0.02) & $0.78(\text { SD } 0.29)^{* \dagger}$ & $1.38(\text { SD } 0.22)^{*}$ & $0.84(\mathrm{SD} 0.12)^{* \dagger}$ & $0.36(\mathrm{SD} 0.07)$ & $1.09(\mathrm{SD} 0.36)$ \\
\hline
\end{tabular}

Values are means (SD) (in 1/min) for $\mathrm{O}_{2}$ delivery and $\mathrm{O}_{2}$ uptake $\left(\mathrm{V}_{2}\right)$. Maximal exercise values were obtained in only 3 subjects (not included in statistical analysis). $* P<0.05$ compared with leg exercise. $\dagger P<0.05$ compared with double poling.

content arterial-venous differences (a-vDif) were lower during arm exercise compared with the other exercise modes, whereas the arm $\mathrm{O}_{2}$ a-vDif was lowest during leg skiing (Fig. 2A). Regardless of the exercise mode, the percentage of $\mathrm{O}_{2}$ extraction was always higher for the legs than for the arms, even during double poling (Fig. 2B). During diagonal skiing, the femoral vein $\mathrm{O}_{2}$ extraction values were slightly greater when the exercise was preceded by the double poling bout than during the $40 \mathrm{~min}$ of continuous diagonal skiing (Fig. 2B).

The exercise $\mathrm{PO}_{2}$ and $\mathrm{O}_{2}$ content values were always lower in the femoral vein than in the subclavian vein, whereas the $\mathrm{O}_{2}$ tension and content values in the blood of the right atrium were in between (Fig. 3, $A$ and $B$ ). Even when the subjects used the double poling technique, which elicited a similar $\mathrm{V}_{2}$ in the arms and legs (Table 1), the $\mathrm{Po}_{2}$ and $\mathrm{O}_{2}$ content values were lower in the femoral vein than in the subclavian vein (Fig. 3, A and $B$ ). Leg $\mathrm{O}_{2}$ extraction was closely related to arm $\mathrm{O}_{2}$ extraction during submaximal exercise with the diagonal stride technique $(r=0.89, P<0.05)$. As shown in Fig. $4 A$, leg mean $\mathrm{O}_{2}$ extraction correlated closely with mean leg $\dot{\mathrm{V}}_{2}$ across conditions $(r=0.89, P<0.05 ; n=6)$, whereas this relationship was not significant at the arm level $(r=0.61, P=0.28$; $n=6$ ). During arm exercise, there also was a close relationship between the mean $\mathrm{O}_{2}$ extraction and the corresponding $\mathrm{P}_{50}$ value $(r=0.93, P<0.05)$ (Fig. $4 B$ ).

$\mathrm{O}_{2}$ off-loading and arm diffusing capacity. As shown in Table 3, during the $40 \mathrm{~min}$ of continuous diagonal skiing, the in vivo $\mathrm{P}_{50}$ value was lower than during the second bout of diagonal exercise, which was performed just after the double poling (33.7 (SD 1.2) and 35.2 (SD 1.5) $\mathrm{mmHg}$, respectively. During combined leg and arm exercise, the blood $\mathrm{pH}$ was similar in the femoral and subclavian veins (Fig. 3C). How-

Table 2. Blood gases, $p H$, and lactate during skiing with different techniques

\begin{tabular}{|c|c|c|c|c|c|c|}
\hline & Resting & Diagonal Skiing & Double Poling & Diagonal Skiing & Leg Skiing & $\begin{array}{l}\text { Diagonal Skiing } \\
\text { (Maximal) }\end{array}$ \\
\hline \multicolumn{7}{|l|}{$\mathrm{PO}_{2}, \mathrm{mmHg}$} \\
\hline Femoral artery & 101.4 (SD 2.9) & $90.9(\text { SD } 7.3)^{*}+$ & $105.1(\mathrm{SD} 6.6)$ & 95.1 (SD 6.9)末 & 93.6 (SD 6.9)‡ & $87.0($ SD 6.1$)$ \\
\hline Subclavian vein & 37.9 (SD 7.6) & $22.2(\text { SD } 2.7)^{*+\dagger}$ & $26.5($ SD 2.0$) *$ & $21.7(\text { SD } 2.7)^{*}+\ddagger$ & $27.8($ SD 5.4)* & 18.0 (SD 1.4) \\
\hline Right atrium & 42.7 (SD 1.7) & $21.3($ SD 3.7)* & $22.5(\mathrm{SD} 2.2)^{*}$ & $19.2(\mathrm{SD} 2.0)^{*}$ & $19.6(\mathrm{SD} 2.4)^{*} \ddagger$ & $15.8(\mathrm{SD} 0.5)$ \\
\hline \multicolumn{7}{|l|}{$\mathrm{SO}_{2}, \%$} \\
\hline Subclavian vein & 71.9 (SD 13.2) & $26.5(\text { SD } 6.1)^{* \dagger}$ & $30.8(\mathrm{SD} 8.3) *$ & $24.0(\text { SD } 7.3)^{* \ddagger}$ & $44.8(\text { SD } 10.3)^{*} \ddagger$ & $13.6(\mathrm{SD} 2.8)$ \\
\hline Right atrium & $80.6(\mathrm{SD} 2.9)$ & $23.4($ SD 5.4)*† & $24.7(\mathrm{SD} 4.4)^{*}$ & $18.0($ SD 5.1)*t & $19.6(\text { SD } 4.7)^{* \ddagger}$ & 10.1 (SD 1.6) \\
\hline \multicolumn{7}{|l|}{$\mathrm{O}_{2}$ content, $\mathrm{ml} / 1$} \\
\hline Femoral artery & $196.2(\mathrm{SD} 4.2)$ & 194.1 (SD 9.8) & 192.7 (SD 9.6) & 188.8 (SD 9.1) & $192.4($ SD 7.3) & $190.0(\mathrm{SD} 7.8)$ \\
\hline Femoral vein & $147.8(\mathrm{SD} 25.0)$ & $26.2(\operatorname{SD~7.3}) * \ddagger$ & $32.3(\mathrm{SD} 12.5)^{*}$ & $18.4(\mathrm{SD} 7.8)^{* \neq}$ & $23.4(\mathrm{SD} 7.8)^{* \dagger}$ & $12.5(\mathrm{SD} 4.2)$ \\
\hline Subclavian vein & $138.2(\mathrm{SD} 38.7)$ & $54.6(\text { SD } 13.0)^{* \dagger}$ & $61.3($ SD 17.4)* & $47.5(\text { SD } 15.7)^{*} \dagger$ & $89.4($ SD 22.3$) * \ddagger$ & $27.9($ SD 5.2) \\
\hline Right atrium & $161.7($ SD 5.6) & $47.4(\text { SD } 12.0)^{* \dagger}$ & $48.4($ SD 8.3$) *$ & 36.0 (SD 10.8)* & $39.5($ SD 10.0$) * \ddagger$ & $20.1($ SD 3.1) \\
\hline \multicolumn{7}{|l|}{$\mathrm{pH}$} \\
\hline Femoral artery & $7.41(\mathrm{SD} 0.02)$ & $7.36(\mathrm{SD} 0.02)^{*}$ & $7.34(\mathrm{SD} 0.02)^{*}$ & $7.32(\mathrm{SD} 0.05)^{*}$ & $7.35(\mathrm{SD} 0.02)^{*}$ & $7.33(\mathrm{SD} 0.03)$ \\
\hline Femoral vein & 7.38 (SD 0.02) & $7.25(\mathrm{SD} 0.02)^{*}$ & $7.24(\text { SD } 0.02)^{*}$ & $7.23(\mathrm{SD} 0.05)^{*}$ & $7.23(\text { SD } 0.02)^{*}$ & $7.19(\mathrm{SD} 0.05)$ \\
\hline Subclavian vein & 7.39 (SD 0.02) & $7.25(\text { SD } 0.02)^{* \dagger}$ & $7.19(\mathrm{SD} 0.02)^{*}$ & $7.22(\text { SD } 0.07)^{*} \dagger$ & $7.30($ SD 0.05$) * \ddagger$ & 7.15 (SD 0.07) \\
\hline Right atrium & 7.39 (SD 0.02) & $7.26(\text { SD } 0.02)^{* \dagger}$ & $7.22(\mathrm{SD} 0.02)^{*}$ & $7.23(\text { SD } 0.07)^{*}$ & $7.26($ SD 0.02$) * \ddagger$ & 7.17 (SD 0.05) \\
\hline \multicolumn{7}{|c|}{ Lactate level, mmol/l } \\
\hline Femoral artery & $0.6(\mathrm{SD} 0.2)$ & $2.6(\mathrm{SD} 1.0)^{*}+\ddagger$ & $7.5(\mathrm{SD} 1.7)^{*}$ & $6.3(\mathrm{SD} 3.4)^{*}$ & $5.0(\mathrm{SD} 2.0)^{*}+$ & $8.1(\mathrm{SD} 1.9)$ \\
\hline Femoral vein & 0.7 (SD 0.2) & $2.4(\text { SD } 1.0)^{*} \dagger \dagger$ & 5.9 (SD 1.7)* & $6.1(\mathrm{SD} 2.9) *$ & $5.1(\mathrm{SD} 2.0)^{*}$ & 7.5 (SD 2.3) \\
\hline Subclavian vein & 0.7 (SD 0.2) & $3.3(\text { SD } 1.2)^{*} \ddagger$ & $9.0(\mathrm{SD} 2.7)^{*}$ & $6.4(\mathrm{SD} 4.7)^{*}$ & $4.7(\mathrm{SD} 2.0)^{*}+$ & $10.2(\mathrm{SD} 2.8)$ \\
\hline Right atrium & $0.6(\mathrm{SD} 0.2)$ & $2.7(\text { SD } 1.0)^{*}+\ddagger$ & $8.6(\mathrm{SD} 2.0)^{*}$ & $6.7(\mathrm{SD} 3.7)^{*}$ & $5.0(\mathrm{SD} 2.2)^{*}+$ & $8.9(\mathrm{SD} 2.8)$ \\
\hline
\end{tabular}

Values are means (SD). $\mathrm{SO}_{2}, \mathrm{O}_{2}$ saturation. Maximal exercise values were obtained in only 3 subjects (not included in statistical analysis). $* P<0.05$ compared with resting conditions. $† P<0.05$ compared with leg exercise. $\ddagger P<0.05$ compared with double poling. 

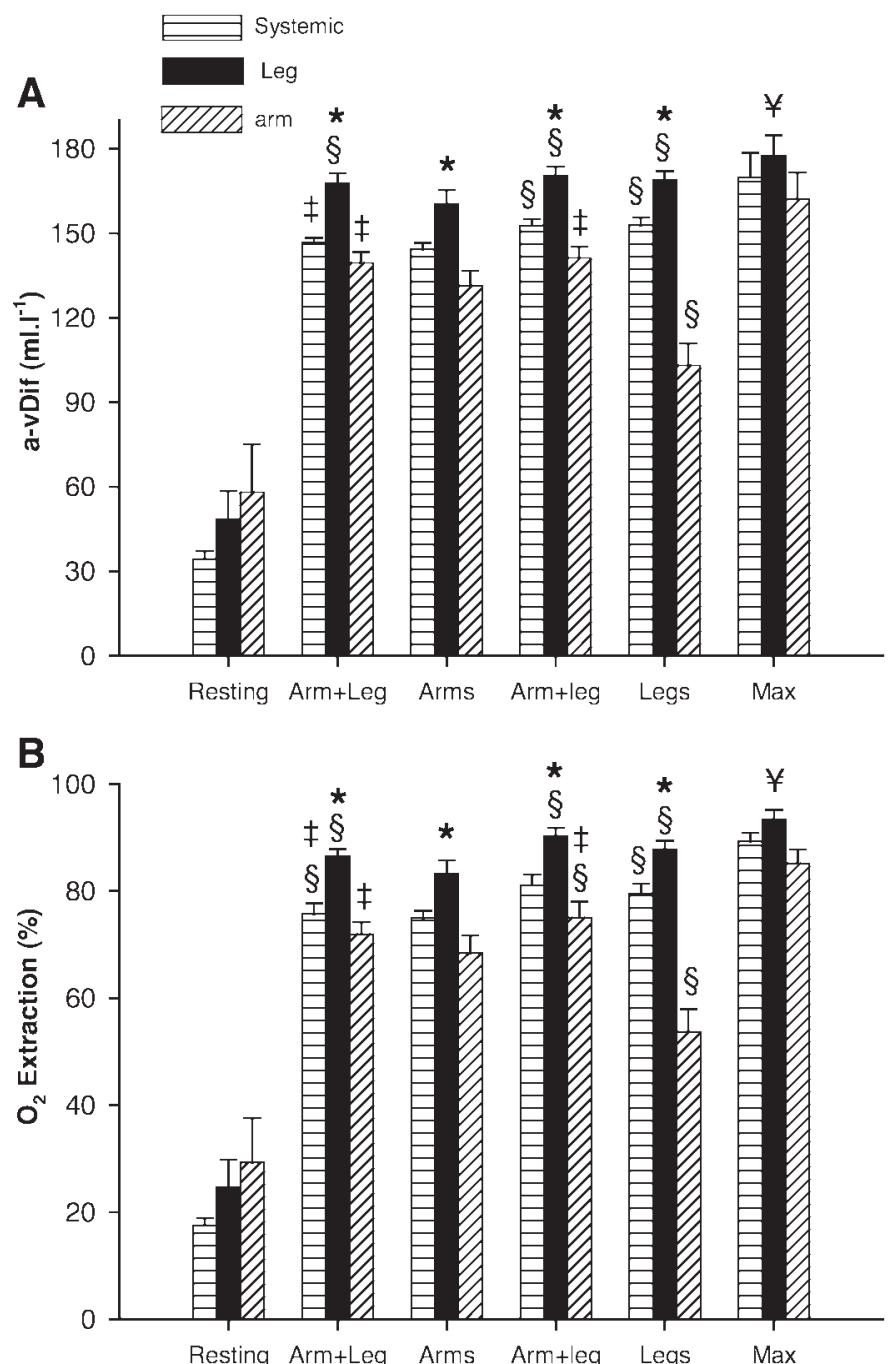

Fig. 2. Systemic, leg, and arm $\mathrm{O}_{2}$ arterial-venous difference (a-vDif) $(A)$ and $\mathrm{O}_{2}$ extraction $(B)$ values were measured during exercise with arms and legs (diagonal stride: arm + leg), with only arms (double poling), and with only legs (leg skiing without poles) and during maximal exercise with the diagonal stride technique (max). ${ }^{*} P<0.05$, comparison between legs and arms during the same exercise condition. $\S P<0.05$ compared with double poling. $\ddagger P<$ 0.05 compared with leg skiing. $¥ P<0.05$, comparison between legs and arms during maximal exercise $(n=3)$. Error bars represent the SE of the mean.

ever, during double poling, the blood $\mathrm{pH}$ was lower in the subclavian than in the femoral vein, whereas the opposite was true during leg skiing. The lower extraction capacity of the arm was not related to differences in the variables that regulate the unloading of $\mathrm{O}_{2}$ from the $\mathrm{Hb}$, because the degree of acidification of blood, blood temperature (not shown), and $\mathrm{PCO}_{2}$ (Fig. $3 D$ ) were very similar in the effluent blood from the legs and arms. However, compared with the subclavian vein, a small, but significantly higher blood temperature $(+0.6$ degrees $)$ and $\mathrm{PCO}_{2}(6-10 \mathrm{mmHg})$ were observed in the femoral vein during leg skiing. Thus the calculated in vivo $\mathrm{P}_{50}$ value was almost the same in the effluent blood from the arm muscles during double poling and the effluent blood from the leg muscles during leg skiing (35.9 (SD 1.7) and 35.8 (SD 1.5) $\mathrm{mmHg}$, respectively, $P=0.66$ ) (Table 3). Despite this high $\mathrm{P}_{50}$ value in the arms, which was significantly higher than the 34.6 (SD 1.5) $\mathrm{mmHg}$ observed in the legs, the $\mathrm{O}_{2}$ extraction was markedly higher in the legs than in the arms during double poling (Fig. $2 B$ ).

At maximal exercise with the diagonal technique, the arm and leg in vivo $\mathrm{P}_{50}$ values were 38.8 (SD 4.3) and 37.5 (SD 3.1) $\mathrm{mmHg}$ (mean of 3 subjects). In the latter condition, one skier was able to extract 97 and $89 \%$ of the $\mathrm{O}_{2}$ supplied to legs and the arms, respectively. This superb $\mathrm{O}_{2}$ extraction was achieved with in vivo $\mathrm{P}_{50}$ values of 41.0 and $43.7 \mathrm{mmHg}$, respectively.

The calculated mean capillary muscle $\mathrm{O}_{2}$ conductance of the arm muscles during double poling was 14.5 (SD 2.6) $\mathrm{ml} \cdot \mathrm{min}^{-1} \cdot \mathrm{mmHg}^{-1}$, and the mean capillary $\mathrm{Po}_{2}$ was 47.7 (SD 2.6) $\mathrm{mmHg}$. The corresponding values for the leg muscles during maximal exercise with the diagonal technique were 48.3 (SD 13.0) $\mathrm{ml} \cdot \mathrm{min}^{-1} \cdot \mathrm{mmHg}^{-1}$ and 33.8 (SD 2.6) $\mathrm{mmHg}$. Arm muscle capillary $\mathrm{O}_{2}$ conductance tended to correlate with maximal arm $\mathrm{O}_{2}$ extraction percentage $(r=0.76, P=0.08)$.

\section{DISCUSSION}

This study shows that in arms, but not in legs, mean $\mathrm{O}_{2}$ extraction is closely related to the mean in vivo $\mathrm{P}_{50}$ value. Moreover, for a given $\mathrm{P}_{50}$ value, the upper extremities extract less $\mathrm{O}_{2}$ than the lower extremities in humans with highly trained arm and leg muscles during exercise. This lower $\mathrm{O}_{2}$ extraction is associated with a lower $\mathrm{O}_{2}$ conductance in the upper compared with the lower extremities. Hence, for a given $\mathrm{O}_{2}$ demand, a greater $\mathrm{O}_{2}$ delivery is needed for exercising arm than leg muscles, which is the cause of the relatively high blood flow to the arms.

Because $\mathrm{O}_{2}$ extraction increases with exercise intensity, and the relative intensity during double poling was $\sim 86 \%$ of double poling $\dot{\mathrm{V}}_{2}$ peak, $\mathrm{O}_{2}$ extraction should have been higher for the arms than for the legs. However, the experimental findings showed higher extraction in the legs than in the arms. This aspect confers additional robustness to our findings.

Arm $\mathrm{O}_{2}$ extraction in trained and untrained muscles. Rasmussen et al. (51) reported mean axillary vein $\mathrm{O}_{2}$ saturation values of 38\% (extraction: 60\%) during arm cranking at an intensity eliciting a heart rate of 170 beats $/ \mathrm{min}$. In the current investigation, the subclavian vein saturation during submaximal exercise achieved mean values between 24 and $31 \%$ (extraction: 68-75\%). The high arm $\mathrm{O}_{2}$ extraction capacity in the current investigation is likely the result of several years of regular training, given that Rasmussen et al. (51) reported that after 5 wk of intensive arm training ( $1 \mathrm{~h} \times 5$ days/wk), the extraction capacity of the arm muscles was only slightly improved. During maximal exercise, the arm muscles of our skiers extracted $85 \%$ of the $\mathrm{O}_{2}$ supplied, which is higher than reported during maximal cycle ergometry in the leg muscles of untrained people before (59) and even after 9 wk of a training program resulting in a $35 \%$ higher $\dot{\mathrm{V}}_{2}{ }_{2}$ max $(59)$. These skiers attained in their arms the same $\mathrm{O}_{2}$ extracting values as we have observed in the legs of physically active subjects $\left(\dot{\mathrm{V}}_{2}\right.$ max between 47 and $63 \mathrm{ml} \cdot \mathrm{kg}^{-1} \cdot \mathrm{min}^{-1}$ ) during upright maximal leg cycle ergometry $(7,68)$. Roca et al. (59) reported maximal leg extraction values of $72 \%$ in sedentary subjects that increased to $82 \%$ after 9 wk of training. Compared with these values, our skiers also reached remarkably high maximal $\mathrm{O}_{2}$ extraction values in their legs $(93 \%)$. However, untrained 

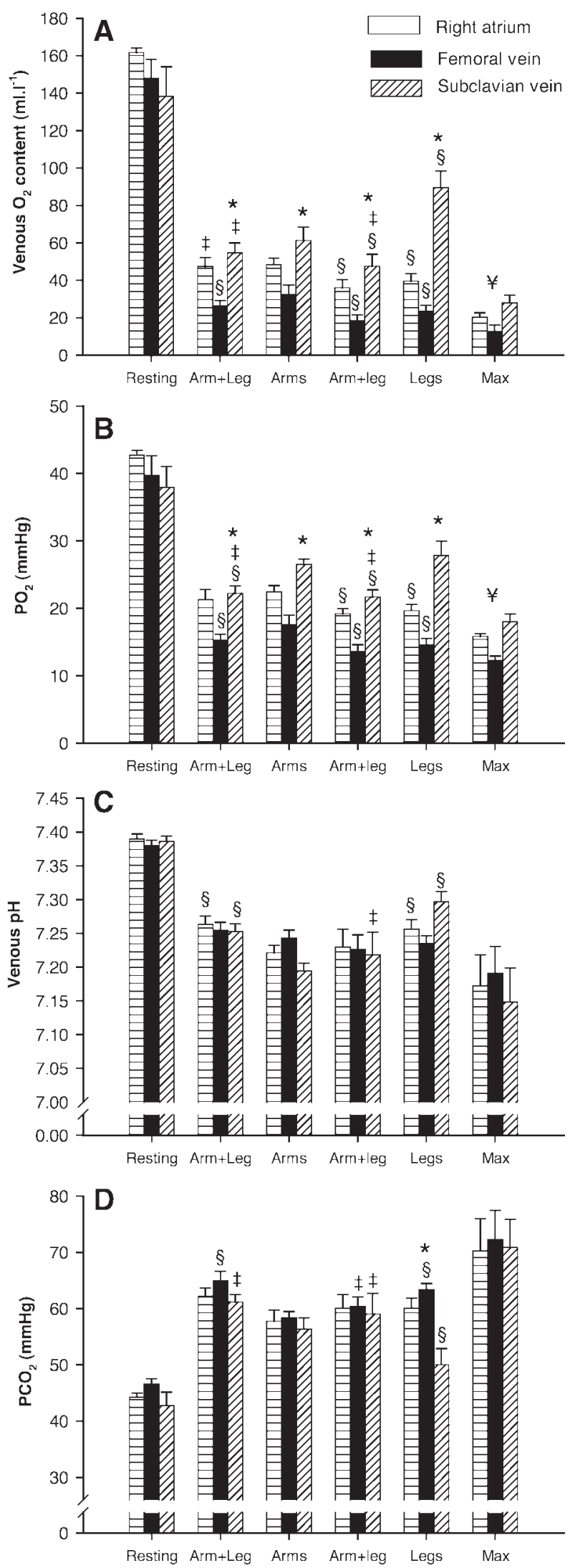
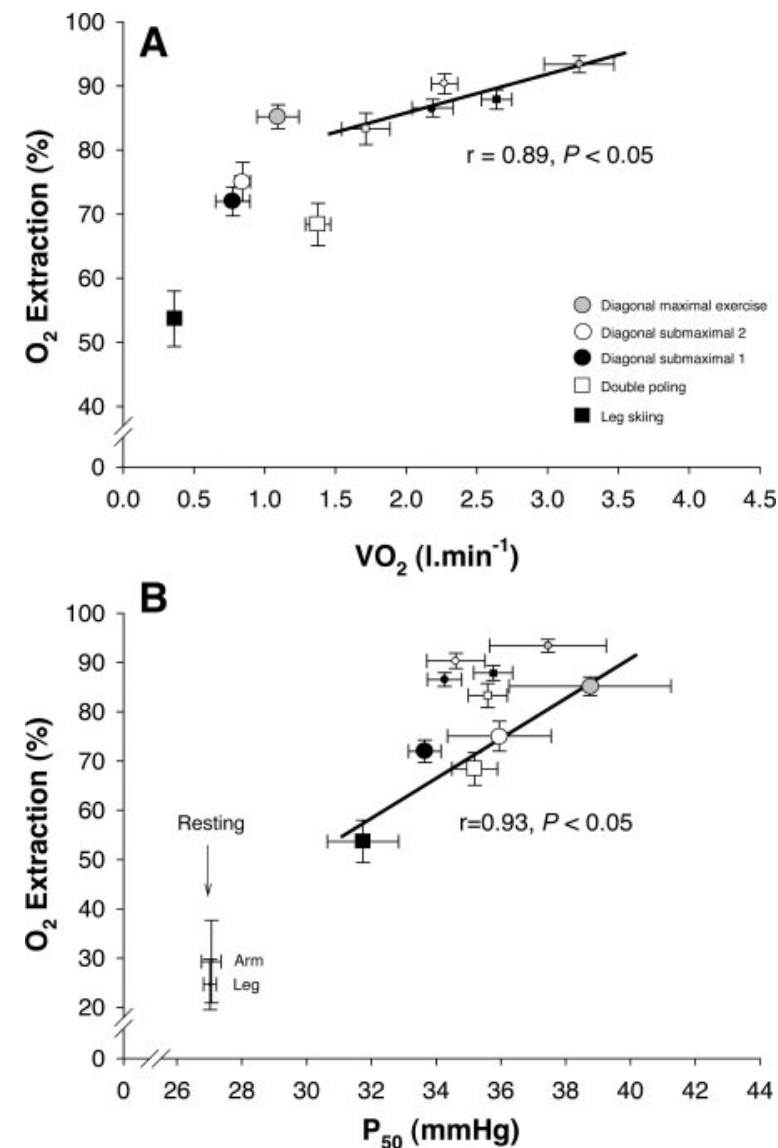

Fig. 4. Relationship between $\mathrm{O}_{2}$ extraction and limb $\dot{\mathrm{V}}_{2}(A)$ or $\mathrm{P}_{50}$, the $\mathrm{PO}_{2}$ value that causes $\mathrm{Hb}$ to be saturated by $50 \%(B)$. Measurements were performed during exercise with arms and legs (diagonal stride), with only arms (double poling), and with only legs (leg skiing without poles) and during maximal exercise with the diagonal stride technique. Small symbols represent leg values; large symbols represent arm values. It is remarkable that leg $\mathrm{O}_{2}$ extraction appears to be more dependent on leg $\mathrm{V}_{2}$ than on the $\mathrm{P}_{50}$ value, whereas arm $\mathrm{O}_{2}$ extraction seems more dependent on the $\mathrm{P}_{50}$ value than on the local $\dot{\mathrm{V}}_{2}$. Error bars represent the SE of the mean.

subjects may reach rather high leg $\mathrm{O}_{2}$ extractions after bed rest (62) or during ischemic exercise (46).

Several factors may account for the observed differences in muscular $\mathrm{O}_{2}$ extraction, which depends on the interaction of the following: 1) kinetics of $\mathrm{O}_{2}$ off-loading from the $\mathrm{Hb} ; 2$ ) capillary muscle $\mathrm{O}_{2}$ conductance $(72) ; 3$ ) blood flow, mean transit time (47), and degree of mismatch between the metabolic demand and blood flow distribution and/or degree of shunt (48); and 4) muscle maximal oxidative capacity (22) and exercise intensity.

Kinetics of $\mathrm{O}_{2}$ off-loading from $\mathrm{Hb}$. The off-loading of $\mathrm{O}_{2}$ from $\mathrm{Hb}$ during exercise is facilitated by acidification of the

Fig. 3. $\mathrm{O}_{2}$ content $(A), \mathrm{Po}_{2}(B)$, pH $(C)$, and $\mathrm{PCO}_{2}(D)$ were measured in the right atrium, femoral vein, and subclavian vein. Measurements were performed during exercise with arms and legs (diagonal stride), with only arms (double poling), and with only legs (leg skiing without poles) and during maximal exercise with the diagonal stride technique. $* P<0.05$, comparison between legs and arms during the same exercise condition. $\S P<0.05$ compared with double poling. $\ddagger P<0.05$ compared with leg skiing. $¥ P<0.05$, comparison between leg and arms at maximal exercise $(n=3)$. Error bars represent the SE of the mean. 
Table 3. Resting and exercise $P_{50} \mathrm{mmHg}$ in effluent blood of the arm (subclavian vein) and leg (femoral vein)

\begin{tabular}{|c|c|c|c|c|c|c|}
\hline & Resting & Diagonal Skiing & Double Poling & Diagonal Skiing & Leg Skiing & $\begin{array}{l}\text { Diagonal Skiing } \\
\text { (Maximal) }\end{array}$ \\
\hline Subclavian vein & 27.1 (SD 0.7) & 33.7 (SD 1.2) & $35.9(\mathrm{SD} 1.7) *$ & $35.2(\mathrm{SD} 1.5) \dagger$ & $31.7(\mathrm{SD} 4.4)^{*} \ddagger$ & 38.8 (SD 4.3) \\
\hline Femoral vein & $27.0(\mathrm{SD} 0.5)$ & 34.3 (SD 1.2) & 34.6 (SD 1.5) & $35.6(\mathrm{SD} 2.2)$ & 35.8 (SD 1.5) $\ddagger$ & $37.5(\mathrm{SD} 3.1)$ \\
\hline
\end{tabular}

Values are means \pm SD (in $\mathrm{mmHg}$ ) for $\mathrm{P}_{50}$, the $\mathrm{Po}_{2}$ value at which $\mathrm{Hb}$ is $50 \% \mathrm{O}_{2}$ saturated. Maximal exercise values were obtained in only 3 subjects (not included in statistical analysis). $* P<0.05$ compared with leg exercise. $\dagger P<0.05$ compared with the first bout of diagonal skiing. $\ddagger P<0.05$ compared with double poling.

blood and the increase of temperature and $\mathrm{PCO}_{2}$ (67). Experiments in dogs have shown that $\mathrm{O}_{2}$ extraction at $\dot{\mathrm{V}}_{2}$ max decreases when the $\mathrm{P}_{50}$ of the $\mathrm{Hb}$ is reduced from its normal value of 32 to $23 \mathrm{mmHg}(24)$, whereas it increases when the $\mathrm{P}_{50}$ is raised to $53.2 \mathrm{mmHg}(56)$. In agreement, we observed a close correlation between $\mathrm{O}_{2}$ extraction and $\mathrm{P}_{50}$. Moreover, during diagonal skiing, slightly higher femoral vein $\mathrm{O}_{2}$ extraction values were observed after than before the double poling bout, which elicited a high degree of blood acidification, despite similar $\dot{\mathrm{V}}_{2}$ and leg blood flows in both phases of diagonal skiing. The latter implies that for a given $\dot{\mathrm{V}}_{2}$, facilitating the off-loading of $\mathrm{O}_{2}$ from the $\mathrm{Hb}$ is associated with increased arm and leg $\mathrm{O}_{2}$ extraction values during exercise. Thus our experiment shows that the conditions for the offloading of $\mathrm{O}_{2}$ from the $\mathrm{Hb}$ may influence $\mathrm{O}_{2}$ extraction in the arm and leg muscles. However, despite small differences in blood temperature and the greater release of lactate and protons during the arm exercise $(29,69)$, the conditions at which the $\mathrm{O}_{2}$ dissociation curve of $\mathrm{Hb}$ operates are similar in the arm and leg muscles (see Fig. 3). Thus the lower arm $\mathrm{O}_{2}$ extraction capacity cannot be explained by a slower off-loading of $\mathrm{O}_{2}$ from the $\mathrm{Hb}$ in the arms, because the in vivo affinity of $\mathrm{Hb}$ for $\mathrm{O}_{2}$ was similar in the arms and legs during both submaximal and maximal exercise.

Capillary muscle $\mathrm{PO}_{2}$ and $\mathrm{O}_{2}$ conductance. In this investigation we calculated the capillary muscle $\mathrm{O}_{2}$ conductance by assuming that mitochondrial $\mathrm{Po}_{2}$ is very close to $0-2 \mathrm{mmHg}$ during double poling and during maximal exercise with the diagonal technique. This assumption is likely to be true in muscles working near their maximum $(53,64)$. Muscle mass is a major determinant of the muscle capillary $\mathrm{O}_{2}$ conductance. Although it is impossible to know exactly what was the actual muscle mass recruited during the double poling, some estimations can be made. The mean capillary $\mathrm{O}_{2}$ conductance of the whole arm of our skiers was $14.5 \mathrm{ml} \cdot \mathrm{min}^{-1} \cdot \mathrm{mmHg}^{-1}$, i.e., a bit lower than the value of $16.6 \mathrm{ml} \cdot \mathrm{min}^{-1} \cdot \mathrm{mmHg}^{-1}$ reported for the leg muscles in 24 sedentary subjects with a mean body weight of $70 \mathrm{~kg}$ (including 7 women) (10). Assuming that the mean muscle mass of the skiers arms was $4-5 \mathrm{~kg}$ and that the sedentary subjects had a leg muscle mass of $8 \mathrm{~kg}$, it can be estimated that the skiers had $\sim 40-75 \%$ higher muscle capillary $\mathrm{O}_{2}$ conductance in their arm muscles than the sedentary subjects studied by Cardus et al. (10) had in their legs. In physically active subjects we have obtained values of 25 $\mathrm{ml} \cdot \mathrm{min}^{-1} \cdot \mathrm{mmHg}^{-1}$ during knee extensor exercise (57), 42.2 $\mathrm{ml} \cdot \mathrm{min}^{-1} \cdot \mathrm{mmHg}^{-1}$ during maximal exercise on the cycle ergometer in physically active subjects (8), and $55 \mathrm{ml}$. $\mathrm{min}^{-1} \cdot \mathrm{mmHg}^{-1}$ in amateur cyclists (16). Together, these data indicate that cross-country skiers have a rather high capillary muscle $\mathrm{O}_{2}$ conductance in their arms, similar to that observed in the legs of physically active subjects but lower than reported in the leg muscles of well-trained subjects having almost the same maximal cardiac output as our skiers (16). Using the data obtained at maximal exercise, we calculated that the muscle mass-normalized leg capillary muscle $\mathrm{O}_{2}$ conductance is at least $50 \%$ higher in the leg muscles than in the arm muscles, assuming an arm muscle mass of $4-5 \mathrm{~kg}$ and a leg muscle mass of $10-11 \mathrm{~kg}$. These data, combined with the positive relationship observed between the percentage of arm $\mathrm{O}_{2}$ extraction and capillary muscle $\mathrm{O}_{2}$ conductance, suggest that the lower armto-leg capillary muscle $\mathrm{O}_{2}$ conductance may explain part of the lower extraction capacity of the arm muscles than the leg muscles in the elite cross-country skiers. However, the question remains, why is capillary muscle $\mathrm{O}_{2}$ conductance lower in the arm than in the leg muscles?

MTT and heterogeneity in blood flow distribution. A larger MTT may facilitate the transfer of $\mathrm{O}_{2}$ from the erythrocyte to the mitochondria (47). The MTT of the erythrocytes crossing the muscle capillaries during maximal exercise is estimated as $\mathrm{MTT}=\mathrm{CBV} / \mathrm{MBF}$, where $\mathrm{CBV}$ is the capillary blood volume and MBF is the muscle blood flow. In turn, the capillary volume may be calculated from the capillary density (31). We did not measure the capillary density in the current investigation, but from previous studies in elite cross-country skiers of the same level of performance as the present subjects, it appears that the capillary density is similar in arm and leg muscles (Table 4) $(38,39,42)$. With a mean capillary density of 500 capillaries in arm and leg muscles of elite cross-country skiers, a similar MTT through the capillaries is expected in the muscles of the upper and lower extremities. For example, if at maximal exercise the active muscle mass is 4 and $11 \mathrm{~kg}$ in the arm and legs, respectively, the calculated MTT values will be 672 and $674 \mathrm{~ms}$, respectively (31). However, the corresponding values will be 1,195 and $1,198 \mathrm{~ms}$ if an inner mean capillary diameter of $6.0 \mu \mathrm{m}$ rather than $4.5 \mu \mathrm{m}$ is assumed. What these numbers suggest is that MTT is rather high in both upper and lower extremities at maximal exercise. At first sight, MTT does not appear to explain the observed differences in $\mathrm{O}_{2}$ extraction between the arms and legs. However, heterogeneity in macrovascular MTT has been related to $\mathrm{O}_{2}$ extraction during low exercise intensity in humans (30). Nevertheless, macrovascular MTT heterogeneity decreases with exercise intensity, but the degree of skeletal muscle capillary MTT heterogeneity existing at maximal exercise remains unknown. In theory, MTT values lying between 0.3 and a little more than $1 \mathrm{~s}$ are possible (63).

In our experimental conditions, where exercise is performed at maximal intensity, there is no reason to suspect a mismatch, shunt, or differences in capillary length between the perfused and the active fibers (72) in arm and leg muscles $(14,26)$. However, we cannot rule out a greater degree of heterogeneity in the distribution of blood flow between muscles in the arms 
Table 4. $\dot{V} O_{2}$ max , capillary density, CS activity, HAD activity, \% ST, and capillary index of cross-country skiers

\begin{tabular}{|c|c|c|c|c|c|c|c|c|c|c|}
\hline Muscle & $\begin{array}{c}\mathrm{VO}_{2} \max \\
\mathrm{ml} \cdot \mathrm{kg}^{-1} \cdot \mathrm{min}^{-1}\end{array}$ & $n$ & $\begin{array}{l}\text { Capillary } \\
\text { Density, } \\
\text { cap/mm² }\end{array}$ & $\begin{array}{l}\text { CS Activity, } \\
\mu \mathrm{mol} \cdot \mathrm{g} \text { dry } \\
\mathrm{wt}^{-1} \cdot \mathrm{min}^{-1}\end{array}$ & $\begin{array}{l}\text { HAD Activity, } \mu \mathrm{mol} \cdot \mathrm{g} \\
\text { dry } \mathrm{wt}^{-1} \cdot \mathrm{min}^{-1}\end{array}$ & $\% \mathrm{ST}$ & $\begin{array}{l}\text { Mean Fiber } \\
\text { Area, } \mu \mathrm{m}^{2}\end{array}$ & Cap/Fiber & $\begin{array}{l}\text { Capillary } \\
\text { Index }\end{array}$ & Reference \\
\hline Vastus lateralis & 76 & $3^{\mathrm{a}}$ & 654 & 88 & 74 & 72 & 5,200 & 3.4 & 0.0133 & Saltin et al. ${ }^{\mathrm{d}}$ \\
\hline Vastus lateralis & 72 & $6^{\mathrm{b}}$ & & 51 & 38 & & & & & Van Hall et al. (69) \\
\hline Deltoid (posterior) & 76 & $3^{\mathrm{a}}$ & 582 & 76 & 61 & 61 & 5,300 & 3.1 & 0.0118 & Saltin et al. ${ }^{\mathrm{d}}$ \\
\hline Deltoid (posterior) & 76 & $4^{\mathrm{b}}$ & 560 & 68 & 60 & & 5,400 & 3.0 & 0.0115 & Saltin et al. ${ }^{\mathrm{d}}$ \\
\hline Triceps (lateral) & 72 & $8^{\mathrm{b}}$ & 492 & 59 & 34 & 45 & 6,400 & 3.1 & 0.0108 & Mizuno et al. (38) \\
\hline Triceps (lateral) & 71 & $9^{\mathrm{b}}$ & 415 & 55 & 43 & 61 & 7,500 & 3.2 & 0.0104 & Terzis et al. ${ }^{\mathrm{d}}$ \\
\hline Vastus lateralis & 76 & 10 & 422 & 49 & 31 & 69 & 6,100 & 2.5 & 0.0090 & Mygind et al. (39) \\
\hline Triceps (lateral) & 76 & 10 & 373 & 39 & 20 & 51 & 7,400 & 2.7 & 0.0089 & Mygind et al. (39) \\
\hline Rectus femoris & & $17^{\mathrm{c}}$ & 411 & & & & & 2.9 & & Parsons et al. (42) \\
\hline Triceps (lateral) & & $17^{\mathrm{c}}$ & 536 & & & & & 4.9 & & Parsons et al. (42) \\
\hline
\end{tabular}

$\dot{\mathrm{V}}_{2}$ max, maximum $\mathrm{O}_{2}$ uptake; $\mathrm{CS}$, citrate synthase; $\mathrm{HAD}$, 3-hydroxyacyl-CoA dehydrogenase; \%ST, percentage of slow-twitch fibers; Cap, no. of capillaries. Capillary index is the mean no. of capillaries around each fiber per mean muscle fiber perimeter; $n$ represents the no. of cross-country skiers: ${ }^{a}$ top-level skiers, bclose to dite-level skiers, ${ }^{\mathrm{c}} 7$ women and 10 men skiers $\left(\mathrm{V}_{2}\right.$ max not reported). ${ }^{\mathrm{d}}$ Unpublished data.

than in the legs. In fact, electromyographic activity data show large interindividual differences in the degree of recruitment of upper arm muscles during double poling (25). Lower $\mathrm{O}_{2}$ extraction may be expected in the muscles that are less activated, hence also contributing to a low mean $\mathrm{O}_{2}$ extraction of the whole extremity. Moreover, upper compared with lower extremities differ in degree of freedom of movement. Leg flexion and extension is performed in a rigid back and forward pattern with only minor variation in the activation of the different muscles and their functional portions. Arm and shoulder muscles, on the other hand, perform their movements in different positions, resulting in larger variation in the degree of muscle recruitment. Hence the mass of active muscles in the arm and shoulder region may be overestimated in crosscountry skiing. In turn, the actual MTT across the active arm muscles may be shorter than the calculated value of $672 \mathrm{~ms}$ if flow is passing through a smaller capillary bed. In case of a lower active muscle mass in the upper extremity than assumed in this study, the real skeletal muscle $\mathrm{O}_{2}$ conductance of the arms would have been underestimated. However, as explained below, this fact cannot explain alone the observed differences in muscle $\mathrm{O}_{2}$ conductance between arms and legs.

The transfer of $\mathrm{O}_{2}$ from the $\mathrm{Hb}$ to the mitochondria should overcome the resistance imposed by the elements interposed between the $\mathrm{Hb}$ molecule and the mitochondrial matrix. It seems that most of the resistance to the diffusion of $\mathrm{O}_{2}$ from the $\mathrm{Hb}$ to the mitochondria relies on the capillary wall $(23,24$, 56). Increasing the number of capillaries around each fiber (i.e., the amount of capillary-to-muscle fiber exchange surface) is likely the most efficient way to improve the muscle conductance for $\mathrm{O}_{2}$ (72). In fact, endurance training induces an increase in the number of capillaries (2). Capillary proliferation appears more accentuated in elite endurance athletes $(60,63$, 65 ) and the longer the time of sport participation (60). Conditions in which the conductance of $\mathrm{O}_{2}$ has been lowered by reducing the mitochondrial oxidative capacity (36) or by eliminating the presence of myoglobin in the sarcoplasm (18) are associated with capillary proliferation as a compensation mechanism. Although it seems that capillary density is similar in the leg and arms muscles of cross-country skiers (Table 4), the capillary-to-fiber perimeter index (mean number of capil- laries around each fiber/mean muscle fiber perimeter) is slightly higher in the leg than in the arm muscles because of the higher mean fiber cross-sectional area of the arm muscles. Using the data in Table 4, we have calculated a mean capillary index of 0.011 and 0.010 capillaries per micrometer of capillary perimeter in the leg and arm muscles, respectively. Thus the available morphometric data suggest that the diffusional area is lower and the diffusional distance longer in the arm than in the leg muscles.

Muscle oxidative capacity. Despite the great amount of training performed by these subjects with the arm muscles, deltoid muscle oxidative capacity was lower than vastus lateralis oxidative capacity, as reflected by the 25 and $11 \%$ lower $\mathrm{CS}$ and HAD activities in the deltoid compared with the vastus lateralis muscles of our skiers (69). However, no relationship was observed between capillary muscle $\mathrm{O}_{2}$ conductance and the activities of CS and HAD. Previous studies also have reported lower CS and HAD activities in the triceps brachii than in the vastus lateralis in cross-country skiers (39) (Table 4). It is difficult to establish to what extent the role of this reduced oxidative capacity may be in the lower $\mathrm{O}_{2}$ extraction capacity of the arms, but some animal in vitro experiments support this possibility $(22,37,58)$ while others do not $(36)$. In humans, however, prolonged bed rest results in reduced mitochondrial volume and muscle oxidative enzyme activities while $\mathrm{O}_{2}$ extraction during maximal exercise is elevated (13, 62). In addition, the fact that $\mathrm{V}_{2}$ max increases with hyperoxia in the trained quadriceps of elite athletes (52) and patients with restricted physical activity due to respiratory insufficiency (55) suggests that humans, regardless of trained status (21), do not use their maximal mitochondrial oxidative capacity even when exercising at $\dot{\mathrm{V}}_{2}$ max with a small muscle mass (27). In fact, it has been estimated that only $20 \%$ of the muscle mass has to be recruited to tax the maximal oxidative capacity in humans (4). This corresponds well with the observation made in rats that maximal muscle $\mathrm{O}_{2}$ extraction remains unchanged despite a 45 and $30 \%$ reduction in cytochrome oxidase and of CS activity, respectively (36). Despite the fact that the arm oxidative capacity of the elite cross-country skiers is lower than their leg muscle oxidative capacity (39), it is likely far in excess of their respective maximal $\mathrm{O}_{2}$ demand (4). In support, we can argue 
that rowing $\dot{\mathrm{V}}_{2}$ max increases with hyperoxia in elite rowers, a discipline in which there is a substantial contribution of the arms to the exercise $\dot{\mathrm{V}}_{2}$ max $(41,45)$. In addition, Clausen et al. (11) showed that after $5 \mathrm{wk}$ of leg training, the whole body $\dot{\mathrm{V}}_{2}$ during maximal arm cranking increased by $10 \%$, whereas the arm arterial-venous difference in $\mathrm{O}_{2}$ content remain unchanged. Thus our data and those summarized in Table 4 suggest that the small difference in oxidative capacity between arm and leg muscles has a minor role, if any, in the lower maximal arm $\mathrm{O}_{2}$ extraction capacity.

Increased arm vascular reactivity? Under resting conditions, the forearms have higher vasodilatory responsiveness to acetylcholine, substance P, nitroprusside (40), and isoproterenol (28) and lower vasoconstricting responsiveness to phenylephrine ( $\alpha_{1}$ agonist) (43). These functional differences between arms and legs suggest increased ability to maintain vasodilation in the arms than in the legs under some level of ongoing sympathetic activation. Thus our data could be interpreted to indicate that the lower $\mathrm{O}_{2}$ extraction in the arms only reflects a compensation for the relatively greater perfusion of the arms compared with the legs. However, if the reason for the lower $\mathrm{O}_{2}$ extraction of the arms was that the arms vasodilated in excess, then $\mathrm{O}_{2}$ extraction should have been similar in arms and legs at peak exercise with the diagonal style, because during this condition, perfusion of the arm and legs is limited by the pumping capacity of the heart (9). Nevertheless, peak arm blood flow reached a much lower value during maximal combined arm and leg exercise than during double poling, while $\mathrm{O}_{2}$ extraction remained at a lower level in the arms than in the legs. Although the reported higher vascular reactivity of the forearm at rest may facilitate the vasodilatory response in the arms during combined arm and leg exercise, it remains unknown whether vascular reactivity remains higher in the arm than in the leg muscles during exercise. It may be that it does not, given that vascular reactivity during exercise is modulated by the compound action of several vasodilating and vasoconstricting agents (12). For example, despite a similar sympathetic activation in arms and legs in response to the cold pressor test, vascular resistance increases in the arms but not in the legs (28). Thus it is possible that during near-maximal combined arm and leg exercise, the exercise-induced elevation of muscle sympathetic nerve activity is likely more efficiently counteracted in the legs than in the arms, i.e., reducing the vasodilatory response of the arms more than that of the legs (66). This mechanism will give the perfusing priority to the main locomotory muscles. However, in case of competition for blood flow between the leg muscles and the respiratory muscles, the perfusion priority is likely given to the respiratory muscles (19).

Potential limitations. Although limited by the fact that $\mathrm{O}_{2}$ extraction at maximal exercise intensity was not determined during isolated exercise with either the upper and the lower extremities, our results are clear: $\mathrm{O}_{2}$ extraction across the upper extremities is lower than oxygen extraction across the lower extremities at a given absolute and relative exercise intensity. Given the fact that venous effluent blood from either extremity drains blood principally coming from the active muscles, the skin, and the bone marrow, the calculated extraction values represent the mean extraction capacity of the whole extremity. In theory, the skeletal muscles of both extremities could have a similar $\mathrm{O}_{2}$ extraction capacity if the degree of "venous admixture," i.e., the amount of blood coming from the bone marrow and the cutaneous circulation at the sampling point, is higher in the arms than in the legs. However, the magnitude of the differences in fractional $\mathrm{O}_{2}$ extraction between legs and arms is too high to be accounted for by different degrees of venous admixture. Of all potential contributors to venous admixture, skin blood flow is quantitatively the most important. Skin blood flow increases with body temperature. In these experiments we took measurements of venous $\mathrm{PO}_{2}$ and $\mathrm{O}_{2}$ extraction after $12 \mathrm{~min}$ of diagonal skiing, and they were repeated after 24 and $36 \mathrm{~min}$ of diagonal skiing (data not shown). During this period, exercise intensity was constant, but body temperature increased significantly from 38.1 to $38.6^{\circ} \mathrm{C}$. Despite this increase in body temperature, and likely in skin blood flow (17), no increase in venous $\mathrm{Po}_{2}$ or reduction in $\mathrm{O}_{2}$ extraction was observed in arms or legs. This suggests that the degree of admixture is small and is not accentuated by a condition that increases skin blood flow. Moreover, we have calculated that during double poling, venous admixture in the upper extremities should have been at least $1.1 \mathrm{l} / \mathrm{min}$ greater than in the lower extremities in case the skeletal muscle $\mathrm{O}_{2}$ extraction values in arm muscles during double poling were similar to the $\mathrm{O}_{2}$ extraction in the leg muscles during leg skiing. This means that total venous admixture should have been $2.2 \mathrm{l} / \mathrm{min}$ higher in the upper than in the lower extremities, which does not seem reasonable because it would imply an impossible regional difference in cutaneous vasodilation between the upper and the lower extremities (34). Moreover, forearm exercise experiments were performed in the 1960s with venous catheters placed in deep forearm veins (under $\mathrm{X}$-ray control) to avoid skin contamination and with a cuff inflated around the wrist at $>200 \mathrm{mmHg}$ to exclude the circulation of the hand (74). In these experiments, maximal exercise extraction values were lower than reported in the current investigation for the whole upper extremity (74).

Even with our state-of-the-art technology it is impossible to know the accurate amount of muscle mass activated during arm or leg exercise. Even worse, it is not possible to know to what extent the motor units are activated. The latter limitation also applies to human models of localized exercise such as the leg extension model. This problem holds for both extremities. The only way to circumvent this limitation is by using animal preparations, which may be stimulated electrically to activate maximally all motor units. However, these preparations show lower $\mathrm{D}_{\mathrm{O}_{2}}$ values than reported in vivo simply because with these preparations $\dot{\mathrm{V}}_{2}$ peak values in most models are $\sim 50 \%$ of the real in vivo $\mathrm{V}_{2}$ peak values. Our lower $\mathrm{D}_{\mathrm{O}_{2}}$ values agree well with the observation of lower $\mathrm{O}_{2}$ extraction capacity for the arms. For an active muscle mass of 5 and $11 \mathrm{~kg}$ in arms and legs, a local muscle $\dot{\mathrm{V}}_{2}$ of 138 and $147 \mathrm{ml} / \mathrm{kg}$ muscle mass can be calculated in the arms during double poling and in the legs during maximal diagonal stride, respectively. The corresponding "muscle-mass-normalized $\mathrm{D}_{\mathrm{O}_{2}}$ " is 2.9 and $4.4 \mathrm{ml} \cdot \mathrm{min}^{-1}$. $\mathrm{mmHg}^{-1} \cdot \mathrm{kg}$ muscle mass ${ }^{-1}$. Arm muscle mass-normalized $\mathrm{D}_{\mathrm{O}_{2}}$ would have matched leg muscle-mass-normalized $\mathrm{D}_{\mathrm{O}_{2}}$ for an active muscle mass of $3.3 \mathrm{~kg}$ in the arms and $11 \mathrm{~kg}$ in the legs. This proportion 3.3/11 (arm/leg active muscle mass) allows for a match in muscle mass-normalized $\mathrm{D}_{\mathrm{O}_{2}}$ between arm and leg muscles but is simply impossible, because the $\dot{\mathrm{V}}_{2}$ peak per kilogram of active muscle mass would have been 209 and $147 \mathrm{ml} / \mathrm{kg}$, i.e., $42 \%$ higher in the arm than in leg 
muscles. Thus only a lower value of muscle mass-normalized $\mathrm{D}_{\mathrm{O}_{2}}$ in the arm muscles fits both our results and the current scientific knowledge.

In summary, the present investigation shows that $\mathrm{O}_{2}$ extraction is closely related to the in vivo $\mathrm{P}_{50}$ during arm exercise in humans with highly endurance trained arm and leg muscles. However, for a given $\mathrm{P}_{50}$ value, the arms have lower $\mathrm{O}_{2}$ extraction and lower capillary muscle $\mathrm{O}_{2}$ conductance values than the leg muscles. Because the conditions for the $\mathrm{O}_{2}$ off-loading from the $\mathrm{Hb}$ are similar in leg and arm muscles, the observed differences in maximal arm and leg $\mathrm{O}_{2}$ extraction should be attributed to other factors, such as a higher diffusing distance and higher heterogeneity in the distribution of blood flow between muscles or functional portions of the same muscle, or lower mean transit time and lower diffusing area in the arms than in the legs. These findings have implications to explain the differences in the cardiorespiratory response to arm vs. leg exercise, because the lower the muscular extraction capacity, the greater should be the blood flow, and hence the cardiovascular effort, to maintain a given metabolic rate.

\section{ACKNOWLEDGMENTS}

We highly appreciate help from the staff and the use of facilities at the Department of Cardiology and Clinical Physiology, Karolinska Hospital, Sweden. We also acknowledge the excellent technical assistance provided by Birgitte Jessen and Karen Juel.

\section{GRANTS}

This study was supported by grants from the Swedish Olympic Committee, Team Danmark, and the Sport Research Council of the Ministry of Culture. The Copenhagen Muscle Research Center is funded by Danish National Research Foundation Grant 504-14.

\section{REFERENCES}

1. Ahlborg G and Jensen-Urstad M. Arm blood flow at rest and during arm exercise. J Appl Physiol 70: 928-933, 1991.

2. Andersen $\mathbf{P}$ and Henriksson J. Capillary supply of the quadriceps femoris muscle of man: adaptive response to exercise. J Physiol 270: 677-690, 1977.

3. Andersen P and Saltin B. Maximal perfusion of skeletal muscle in man. J Physiol 366: 233-249, 1985.

4. Blomstrand E, Radegran G, and Saltin B. Maximum rate of oxygen uptake by human skeletal muscle in relation to maximal activities of enzymes in the Krebs cycle. J Physiol 501: 455-460, 1997.

5. Brooke MH and Kaiser KK. Three "myosin adenosine triphosphatase" systems: the nature of their $\mathrm{pH}$ lability and sulfhydryl dependence. J Histochem Cytochem 18: 670-672, 1970.

6. Calbet JA. Oxygen tension and content in the regulation of limb blood flow. Acta Physiol Scand 168: 465-472, 2000.

7. Calbet JA, Boushel R, Radegran G, Sondergaard H, Wagner PD, and Saltin B. Determinants of maximal oxygen uptake in severe acute hypoxia. Am J Physiol Regul Integr Comp Physiol 284: R291-R303, 2003.

8. Calbet JA, Boushel R, Radegran G, Sondergaard H, Wagner PD, and Saltin B. Why is $\dot{\mathrm{V}}_{2}$ max after altitude acclimatization still reduced despite normalization of arterial $\mathrm{O}_{2}$ content? Am J Physiol Regul Integr Comp Physiol 284: R304-R316, 2003.

9. Calbet JA, Jensen-Urstad M, Van Hall G, Holmberg HC, Rosdahl H, and Saltin B. Maximal muscular vascular conductances during whole body upright exercise in humans. J Physiol 558: 319-331, 2004.

10. Cardus J, Marrades RM, Roca J, Barbera JA, Diaz O, Masclans JR, Rodriguez-Roisin R, and Wagner PD. Effects of $\mathrm{F}_{\mathrm{I}} \mathrm{O}_{2}$ on leg $\mathrm{VO}_{2}$ during cycle ergometry in sedentary subjects. Med Sci Sports Exerc 30: 697-703, 1998.

11. Clausen JP, Klausen K, Rasmussen B, and Trap-Jensen J. Central and peripheral circulatory changes after training of the arms or legs. Am J Physiol 225: 675-682, 1973.

12. Clifford PS and Hellsten Y. Vasodilatory mechanisms in contracting skeletal muscle. J Appl Physiol 97: 393-403, 2004.
13. Ferretti G, Antonutto G, Denis C, Hoppeler H, Minetti AE, Narici MV, and Desplanches D. The interplay of central and peripheral factors in limiting maximal $\mathrm{O}_{2}$ consumption in man after prolonged bed rest. J Physiol 501: 677-686, 1997.

14. Fuglevand AJ and Segal SS. Simulation of motor unit recruitment and microvascular unit perfusion: spatial considerations. J Appl Physiol 83: 1223-1234, 1997.

15. Gayeski TE and Honig CR. $\mathrm{O}_{2}$ gradients from sarcolemma to cell interior in red muscle at maximal $\dot{\mathrm{V}}_{2}$. Am J Physiol Heart Circ Physiol 251: H789-H799, 1986.

16. Gonzalez-Alonso J and Calbet JA. Reductions in systemic and skeletal muscle blood flow and oxygen delivery limit maximal aerobic capacity in humans. Circulation 107: 824-830, 2003.

17. Gonzalez-Alonso J, Calbet JA, and Nielsen B. Muscle blood flow is reduced with dehydration during prolonged exercise in humans. J Physiol 513: 895-905, 1998.

18. Grange RW, Meeson A, Chin E, Lau KS, Stull JT, Shelton JM, Williams RS, and Garry DJ. Functional and molecular adaptations in skeletal muscle of myoglobin-mutant mice. Am J Physiol Cell Physiol 281: C1487-C1494, 2001

19. Harms CA, Babcock MA, McClaran SR, Pegelow DF, Nickele GA, Nelson WB, and Dempsey JA. Respiratory muscle work compromises leg blood flow during maximal exercise. J Appl Physiol 82: 1573-1583, 1997

20. Haseler LJ, Lin AP, and Richardson RS. Skeletal muscle oxidative metabolism in sedentary humans: ${ }^{31} \mathrm{P}-\mathrm{MRS}$ assessment of $\mathrm{O}_{2}$ supply and demand limitations. J Appl Physiol 97: 1077-1081, 2004.

21. Henriksson J and Reitman JS. Time course of changes in human skeletal muscle succinate dehydrogenase and cytochrome oxidase activities and maximal oxygen uptake with physical activity and inactivity. Acta Physiol Scand 99: 91-97, 1977.

22. Hepple RT, Hagen JL, and Krause DJ. Oxidative capacity interacts with oxygen delivery to determine maximal $\mathrm{O}_{2}$ uptake in rat skeletal muscles in situ. J Physiol 541: 1003-1012, 2002.

23. Hepple RT, Hogan MC, Stary C, Bebout DE, Mathieu-Costello O, and Wagner PD. Structural basis of muscle $\mathrm{O}_{2}$ diffusing capacity: evidence from muscle function in situ. J Appl Physiol 88: 560-566, 2000.

24. Hogan MC, Bebout DE, and Wagner PD. Effect of increased $\mathrm{Hb}-\mathrm{O}_{2}$ affinity on $\mathrm{V}_{2}$ max at constant $\mathrm{O}_{2}$ delivery in dog muscle in situ. $J$ Appl Physiol 70: 2656-2662, 1991.

25. Holmberg HC, Lindinger S, Stöggl T, Eizlmeyer E, and Mueller E. Biomechanical analysis of double poling in elite cross-country skiers. Med Sci Sports Exerc 37: 807-818, 2005.

26. Honig CR, Odoroff CL, and Frierson JL. Active and passive capillary control in red muscle at rest and in exercise. Am J Physiol Heart Circ Physiol 243: H196-H206, 1982.

27. Hopman MT, Folgering HT, Groothuis JT, and Houtman S. The effect of inspired oxygen fraction on peak oxygen uptake during arm exercise. Eur J Appl Physiol 90: 120-124, 2003.

28. Jacob G, Costa F, Shannon J, Robertson D, and Biaggioni I. Dissociation between neural and vascular responses to sympathetic stimulation : contribution of local adrenergic receptor function. Hypertension 35: $76-$ $81,2000$.

29. Jensen-Urstad M and Ahlborg G. Is the high lactate release during arm exercise due to a low training status? Clin Physiol 12: 487-496, 1992.

30. Kalliokoski KK, Knuuti J, and Nuutila P. Blood transit time heterogeneity is associated to oxygen extraction in exercising human skeletal muscle. Microvasc Res 67: 125-132, 2004.

31. Kayar SR, Hoppeler H, Jones JH, Longworth K, Armstrong RB, Laughlin MH, Lindstedt SL, Bicudo JE, Groebe K, Taylor CR, and Weibel ER. Capillary blood transit time in muscles in relation to body size and aerobic capacity. J Exp Biol 194: 69-81, 1994.

32. Kelman GR. Digital computer subroutine for the conversion of oxygen tension into saturation. J Appl Physiol 21: 1375-1376, 1966.

33. Knight DR, Schaffartzik W, Poole DC, Hogan MC, Bebout DE, and Wagner PD. Effects of hyperoxia on maximal leg $\mathrm{O}_{2}$ supply and utilization in men. J Appl Physiol 75: 2586-2594, 1993.

34. Kondo N, Takano S, Aoki K, Shibasaki M, Tominaga H, and Inoue Y. Regional differences in the effect of exercise intensity on thermoregulatory sweating and cutaneous vasodilation. Acta Physiol Scand 164: 71-78, 1998.

35. Koskolou MD, Roach RC, Calbet JA, Radegran G, and Saltin B. Cardiovascular responses to dynamic exercise with acute anemia in humans. Am J Physiol Heart Circ Physiol 273: H1787-H1793, 1997. 
36. McAllister RM, Ogilvie RW, and Terjung RL. Impact of reduced cytochrome oxidase activity on peak oxygen consumption of muscle. J Appl Physiol 69: 384-389, 1990.

37. McAllister RM and Terjung RL. Acute inhibition of respiratory capacity of muscle reduces peak oxygen consumption. Am J Physiol Cell Physiol 259: C889-C896, 1990.

38. Mizuno M, Juel C, Bro-Rasmussen T, Mygind E, Schibye B, Rasmussen B, and Saltin B. Limb skeletal muscle adaptation in athletes after training at altitude. J Appl Physiol 68: 496-502, 1990.

39. Mygind E. Fibre characteristics and enzyme levels of arm and leg muscles in elite cross-country skiers. Scand J Med Sci Sports 5: 76-80, 1995.

40. Newcomer SC, Leuenberger UA, Hogeman CS, Handly BD, and Proctor DN. Different vasodilator responses of human arms and legs. J Physiol 556: 1001-1011, 2004.

41. Nielsen HB, Madsen P, Svendsen LB, Roach RC, and Secher NH. The influence of $\mathrm{P}_{\mathrm{a}} \mathrm{O}_{2}, \mathrm{pH}$ and $\mathrm{S}_{\mathrm{a}} \mathrm{O}_{2}$ on maximal oxygen uptake. Acta Physiol Scand 164: 89-87, 1998.

42. Parsons D, McIntyre K, Schultz W, and Stray-Gundersen J. Capillarity of elite cross-country skiers: a lectin (Ulex europaeus I) marker. Scand J Med Sci Sports 3: 89-98, 1993.

43. Pawelczyk JA and Levine BD. Heterogeneous responses of human limbs to infused adrenergic agonists: a gravitational effect? J Appl Physiol 92: 2105-2113, 2002.

44. Pedersen PK, Kiens B, and Saltin B. Hyperoxia does not increase peak muscle oxygen uptake in small muscle group exercise. Acta Physiol Scand 166: 309-318, 1999.

45. Peltonen JE, Rantamaki J, Niittymaki SP, Sweins K, Viitasalo JT, and Rusko HK. Effects of oxygen fraction in inspired air on rowing performance. Med Sci Sports Exerc 27: 573-579, 1995.

46. Pernow B, Saltin B, Wahren J, Cronestrand R, and Ekestroom S. Leg blood flow and muscle metabolism in occlusive arterial disease of the leg before and after reconstructive surgery. Clin Sci Mol Med 49: 265-275, 1975.

47. Piiper J. Perfusion, diffusion and their heterogeneities limiting bloodtissue $\mathrm{O}_{2}$ transfer in muscle. Acta Physiol Scand 168: 603-607, 2000.

48. Piiper J and Haab P. Oxygen supply and uptake in tissue models with unequal distribution of blood flow and shunt. Respir Physiol 84: 261-271, 1991.

49. Poole JG, Lawrenson L, Kim J, Brown C, and Richardson RS. Vascular and metabolic response to cycle exercise in sedentary humans: effect of age. Am J Physiol Heart Circ Physiol 284: H1251-H1259, 2003.

50. Qu Z, Andersen JL, and Zhou S. Visualisation of capillaries in human skeletal muscle. Histochem Cell Biol 107: 169-174, 1997.

51. Rasmussen B, Klausen K, Clausen JP, and Trap-Jensen J. Pulmonary ventilation, blood gases, and blood $\mathrm{pH}$ after training of the arms or the legs. J Appl Physiol 38: 250-256, 1975.

52. Richardson RS, Grassi B, Gavin TP, Haseler LJ, Tagore K, Roca J, and Wagner PD. Evidence of $\mathrm{O}_{2}$ supply-dependent $\mathrm{VO}_{2}$ max in the exercise-trained human quadriceps. J Appl Physiol 86: 1048-1053, 1999.

53. Richardson RS, Newcomer SC, and Noyszewski EA. Skeletal muscle intracellular $\mathrm{PO}_{2}$ assessed by myoglobin desaturation: response to graded exercise. J Appl Physiol 91: 2679-2685, 2001.

54. Richardson RS, Noyszewski EA, Kendrick KF, Leigh JS, and Wagner PD. Myoglobin $\mathrm{O}_{2}$ desaturation during exercise. Evidence of limited $\mathrm{O}_{2}$ transport. J Clin Invest 96: 1916-1926, 1995.
55. Richardson RS, Sheldon J, Poole DC, Hopkins SR, Ries AL, and Wagner PD. Evidence of skeletal muscle metabolic reserve during whole body exercise in patients with chronic obstructive pulmonary disease. Am J Respir Crit Care Med 159: 881-885, 1999.

56. Richardson RS, Tagore K, Haseler LJ, Jordan M, and Wagner PD. Increased $\mathrm{VO}_{2}$ max with right-shifted $\mathrm{Hb}-\mathrm{O}_{2}$ dissociation curve at a constant $\mathrm{O}_{2}$ delivery in dog muscle in situ. J Appl Physiol 84: 995-1002, 1998.

57. Roach RC, Koskolou MD, Calbet JA, and Saltin B. Arterial $\mathrm{O}_{2}$ content and tension in regulation of cardiac output and leg blood flow during exercise in humans. Am J Physiol Heart Circ Physiol 276: H438-H445, 1999.

58. Robinson DM, Ogilvie RW, Tullson PC, and Terjung RL. Increased peak oxygen consumption of trained muscle requires increased electron flux capacity. J Appl Physiol 77: 1941-1952, 1994.

59. Roca J, Agusti AG, Alonso A, Poole DC, Viegas C, Barbera JA, Rodriguez-Roisin R, Ferrer A, and Wagner PD. Effects of training on muscle $\mathrm{O}_{2}$ transport at $\dot{\mathrm{VO}}_{2 \text { max. }}$ J Appl Physiol 73: 1067-1076, 1992.

60. Rodriguez LP, Lopez-Rego J, Calbet JA, Valero R, Varela E, and Ponce J. Effects of training status on fibers of the musculus vastus lateralis in professional road cyclists. Am J Phys Med Rehabil 81: 651-660, 2002.

61. Saltin B. Hemodynamic adaptations to exercise. Am J Cardiol 55: 42D47D, 1985.

62. Saltin B, Blomqvist G, Mitchell JH, Johnson RL Jr, Wildenthal K, and Chapman CB. Response to exercise after bed rest and after training. Circulation 38, Suppl 5: VII1-VII78, 1968.

63. Saltin B and Gollnick PD. Skeletal muscle adaptability: significance for metabolism and performance. In: Handbook of Physiology. Skeletal Muscle. Bethesda, MD: Am Physiol Soc, 1983, sect. 10, p. 555-631.

64. Severinghaus JW. Exercise $\mathrm{O}_{2}$ transport model assuming zero cytochrome $\mathrm{PO}_{2}$ at $\dot{\mathrm{VO}}_{2}$ max. J Appl Physiol 77: 671-678, 1994.

65. Sjøgaard G. Muscle morphology and metabolic potential in elite road cyclists during a season. Int J Sports Med 5: 250-254, 1984.

66. Strange S. Cardiovascular control during concomitant dynamic leg exercise and static arm exercise in humans. J Physiol 514: 283-291, 1999.

67. Stringer W, Wasserman K, Casaburi R, Porszasz J, Maehara K, and French W. Lactic acidosis as a facilitator of oxyhemoglobin dissociation during exercise. J Appl Physiol 76: 1462-1467, 1994.

68. van Hall G, Calbet JA, Sondergaard H, and Saltin B. The re-establishment of the normal blood lactate response to exercise in humans after prolonged acclimatization to altitude. J Physiol 536: 963-975, 2001.

69. Van Hall G, Jensen-Urstad M, Rosdahl H, Holmberg HC, Saltin B, and Calbet JA. Leg and arm lactate and substrate kinetics during exercise. Am J Physiol Endocrinol Metab 284: E193-E205, 2003.

70. Volianitis S and Secher NH. Arm blood flow and metabolism during arm and combined arm and leg exercise in humans. J Physiol 544: 977-984, 2002.

71. Wagner PD. Algebraic analysis of the determinants of $\mathrm{VO}_{2}$ max. Respir Physiol 93: 221-237, 1993.

72. Wagner PD. Diffusive resistance to $\mathrm{O}_{2}$ transport in muscle. Acta Physiol Scand 168: 609-614, 2000.

73. Wagner PD. Gas exchange and peripheral diffusion limitation. Med Sci Sports Exerc 24: 54-58, 1992.

74. Wahren J. Quantitative aspects of blood flow and oxygen uptake in the human forearm during rhythmic exercise. Acta Physiol Scand Suppl 269: 1-93, 1966. 